\title{
Bank Systemic Risk and Corporate Investment: Evidence from the US
}

\author{
Meg Adachi-Sato \\ School of Economics, Finance, and Marketing \\ Royal Melbourne Institute of Technology University \\ Melbourne, Victoria 3000, Australia \\ Tel: +61039925 5450 \\ E-mail: meg.sato@rmit.edu.au \\ Chaiporn Vithessonthi* \\ Sunway University Business School \\ Sunway University \\ No. 5, Jalan Universiti, Bandar Sunway \\ 47500 Selangor Darul Ehsan, Malaysia \\ Tel: +60 374918622 Ext. 7104 Fax: +60 356358633 \\ Email: chaipornv@sunway.edu.my
}

This version: 14 January 2017

*Corresponding author

\section{Acknowledgements}

We thank the Editor and two anonymous referees for constructive comments and valuable feedback. We gratefully acknowledge financial support from the Murata Science Foundation. 


\title{
Bank Systemic Risk and Corporate Investment: Evidence from the US
}

\begin{abstract}
In this paper, we use three measures that arguably capture two dimensions of "bank systemic risk", namely, (1) bank funding maturity and (2) bank asset commonality, to empirically test whether bank systemic risk has a positive effect on corporate investment. We document that in a sample of publicly listed firms in the United States over the period 1991-2013, bank systemic risk is positively associated with the firm-level investment ratio after controlling for a large set of country-level and firm-level variables. In addition, we show that a firm's leverage strengthens the positive effect of bank systemic risk on corporate investment, suggesting that more financially constrained firms experience a larger effect of bank systemic risk on corporate investment than less financially constrained firms.
\end{abstract}

JEL Classification: E22; E44; G1; G21; G31

Keywords: Banking System; Bank Systemic Risk; Corporate Investment; Financial Crisis; Growth Opportunities

\section{Introduction}

This paper examines how bank systemic risk $^{1}$, which is broadly conceptualized as a situation in which a large number of financial institutions (e.g., banks) fail due to a common

\footnotetext{
${ }^{1}$ Bank systemic risk has been measured in a number of ways such as CoVaR (Bernal et al., 2014), Marginal Expected Shortfall (De Jonghe et al., 2015), and funding maturity (Allen et al., 2012a).
} 
shock or a contagion process (see e.g., Acharya et al., 2011), impacts a firm’s investment. We construct three indexes that measure two dimensions of bank systemic risk in a country's banking system; namely, (1) bank funding maturity and (2) bank asset commonality. Using these indexes, we first show that bank systemic risk in terms of bank funding maturity is positively associated with corporate investment, after controlling for a large set of firmspecific and macro-level variables. That is, when the proportion of short-term funding relative to long-term funding of the average bank increases, there is an increase in corporate investment. The effect of bank asset commonality, measured as bank asset commonality, on corporate investment is inconclusive. Overall, the results indicate that bank systemic risk has a positive effect on corporate investment. We also show that the positive effect of bank systemic risk on corporate investment is stronger for firms with higher financial leverage than firms with lower financial leverage.

One of the fundamental questions facing financial market regulators and bank supervisory authorities around the world following banking crises, and in particular, the recent global financial crisis of 2007-2008 is whether variation in bank systemic risk is positively associated with booms in credit markets (e.g., bank loans) that lead to firms' overinvestments (e.g., in capital expenditures). ${ }^{2}$ The degree of overinvestment of firms will pose risk to financial systems as well as the economy.

Given the prevalent findings in the literature that banks' behaviors (e.g., bank revenue diversification and bank capitalization) contribute to bank risk ${ }^{3}$, which in turn affects systemic risk of the financial sector, we develop a simple two-period model in which corporate investment (at the firm level) is related to the degree of bank systemic risk that is driven by the (excessive) use of short-term financing and/or asset commonality across banks

\footnotetext{
${ }^{2}$ See e.g., Myers (1977) and Stulz (1990) for discussion about overinvestments.

${ }^{3}$ See, e.g., Demirgüç-Kunt and Huizinga (2010), Cohen et al. (2014), and Cubillas and González (2014).
} 
in a country. A primary explanation for the relationship between bank systemic risk and corporate investment is that the presence of the moral hazard problem in banks and firms simultaneously causes (1) banks to take on riskier loans, which lead to an increase in the supply of credit provided by the banking system ${ }^{4}$, (2) the level of bank systemic risk to increase, and (3) firms to invest in riskier projects (given that banks are now willing to finance higher risk investments than they were previously used to), which lead to economic growth as well as macroeconomic instability. ${ }^{5}$

A key feature of our theoretical model is that when a probability of bank runs or financial crises (hereafter "financial crises") is positive and banks ex ante internalize the cost of financial crises, the level of banks' investment (e.g., loans) is smaller, relative to a case where the probability of financial crises is zero. When banks ex ante expect to be bailed out during financial crises, they do not necessarily internalize the cost of financial crises. We argue that the level of systemic risk in the banking sector is largely driven by (1) the way in which banks finance their investment using more short-term debt and/or (2) the increase in asset commonality amongst banks. As a result, bank systemic risk and corporate investment are positively correlated. In policy terms, our model indicates that to ameliorate the positive impact of bank systemic risk on corporate investment, financial markets regulators and/or banking supervisory authorities should address the fundamental question of how to impose banks to internalize the costs of a financial crisis that is caused by a high degree of bank systemic risk contributed by each bank in the system. Overall, our arguments are generally resonant with those of Diamond and Rajan (2005) and of Farhi and Tirole (2012).

\footnotetext{
${ }^{4}$ Leth-Petersen (2010) finds the significant response of total expenditure to an exogenous increase in credit in Denmark.

${ }^{5}$ Levine and Zervos (1998) show that financial markets (e.g., stock market liquidity and banking sector development) stimulate economic growth.
} 
Using a panel data set of publicly listed firms in the United States over the period 19912013, we empirically test our main prediction that bank systemic risk is positively associated with corporate investment. Following Allen et al. (2012a), we use SYSRISK1, computed as the ratio of short-term debt to long-term debt, to measure the degree of bank systemic risk in terms of "bank funding maturity". A high value of SYSRISK indicates shorter bank funding maturity, which implies a high degree of bank systemic risk. Following recent studies on bank systemic risk (see e.g., Calmès and Théoret, 2014), we use SYSRISK2, computed as the inverse of the cross-sectional standard deviation of the ratio of total loans to total assets, and SYSRISK3, computed as the inverse of the cross-sectional standard deviation of a share of non-interest income to net revenue, to measure the degree of bank systemic risk in terms of "bank asset commonality".

We document that an increase in bank systemic risk leads to an increase in corporate investment (measured as the investment rate) in a sample of 36,136 firm-year observations. Our key findings can be briefly summarized as follows. First, after controlling for firm-level and country-level variables, SYSRISK1, which indicates "bank funding maturity", is positively associated with the investment rate. We also show that financial leverage strengthens the positive effect of bank systemic risk on corporate investment and that other firm characteristics such as investment opportunities, firm size, and operating performance do not moderate the relationship between bank systemic risk and corporate investment. Second, we find that the effect of SYSRISK2 on corporate investment is insignificant. This finding suggests that bank asset commonality with respect to the banks' loan portfolio has no effect on corporate investment. Third, while there is some evidence for the positive relationship between SYSRISK3 and corporate investment; however, this relationship is not robust. This result indicates that bank asset commonality with respect to non-core banking activities appears to induce firms to invest more. 
Our paper is broadly related to two streams of the literature, namely: (1) corporate investment (see e.g., Denis and Sibilkov, 2010; Hackbarth and Mauer, 2012; Julio and Yook, 2012; Panousi and Papanikolaou, 2012; Titman, 2013) and (2) bank systemic risk (Allen et al., 2012a; Allen et al., 2012b; Anginer et al., 2014; Billio et al., 2012; Gauthier et al., 2012). In this paper, we extend prior studies by combining these two streams of research. Broadly speaking, the corporate finance literature typically does not incorporate macro-level variables in the models (see e.g., Aivazian et al., 2005; Billett et al., 2011; Denis and Sibilkov, 2010; Foucault and Fresard, 2014; Jovanovic and Rousseau, 2014; Panousi and Papanikolaou, 2012), whereas the banking literature mainly focuses on how banks' activities/behaviors create idiosyncratic (bank-specific) and systemic risk (of the banking system) and generally does not analyze the effect of bank-level factors on firm-level investment (see e.g., Allen et al., 2012a; Anginer et al., 2014; Bedendo and Bruno, 2012; Billio et al., 2012; Calmès and Théoret, 2014; Duran and Lozano-Vivas, 2014). Therefore, our study complements both streams of research by providing new empirical evidence on the influence of bank systemic risk on firm-level investment. In addition, our paper is also closely related to prior studies such as those of Bianchi (2011) and Lorenzoni (2008), who examine the effects of credit booms on corporate investment.

The rest of this paper is organized as follows. In Section 2 we provide a brief overview of related studies and present hypotheses. In Section 3 we describe our data and research methodology. In Section 4 we report and discuss our empirical results and implications for the banking and corporate finance literature. In Section 5 we conclude the paper.

\section{Related literature and hypothesis development}




\subsection{Related literature on rollover risk and systemic risk}

As noted by He and Xiong (2012), a firm faces roll over risk of not being able to roll over matured short-term debt with the issuance of new short-term debt. ${ }^{6}$ They also argue that the firm's rollover risk is affected by debt maturity because the rollover losses of all bonds with shorter maturity at a certain date causes equity holders to suddenly absorb rollover losses, and the effect of debt maturity on rollover risk is magnified by the degree of market liquidity. In the model of Acharya et al. (2011), a sudden "market freeze" phenomenon, which refers to a situation in which a sudden collapse of firms' ability to borrow short-term, causes the firms to fail to rollover their short-term debt. The collapse of short-term debt markets (e.g., interbank markets) is arguably considered to be one of the key drivers of the 2007-2008 global financial crisis (Acharya et al., 2011; Iyer et al., 2014).

Rollover risk typically increases with systemic risk. According to Allen et al. (2012a), the term "systemic risk" traditionally refers to (1) a situation in which a large number of financial institutions (e.g., banks) fail due to a common stock or a contagion process, (2) the connections between financial institutions, and (3) financial institutions' funding maturity. Schotter and Yorulmazer (2009) note that many static two-period models on bank runs view a bank-run problem as an equilibrium selection problem and focus the analysis on whether in the presence of a probability of a run on a bank, deposit contracts are optimal arrangements. Therefore, they develop a dynamic four-period bank-run model that focuses on the dynamics and severity of bank runs. One of the key insights resulting from their model is that money stays longer in the banking system in the presence of insider information (i.e. those who are

\footnotetext{
${ }^{6} \mathrm{He}$ and Xiong (2012) note that the firm may suffer rollover losses when the value of new debt issuance is less than the value of the maturing debt, which may affect the value of existing equity.
} 
informed about the soundness of the banks); that is, withdrawals tend to be made later when there are insiders, relative to when there is no insider.

López-Espinosa et al. (2012) find that short-term wholesale funding determines a bank’s contribution to systemic risk, and that banks with high levels of short-term funding are more interconnected to other banks and more vulnerable to changes in market conditions and liquidity risk. Furthermore, Uhde and Michalak (2010) show that the variation in European banks' systemic risk can be explained by credit risk securitization. In the model of Allen et al. (2012a), when banks use long-term debt, the welfare is not affected by the asset structure of the banks, but when short-term debt is used, the asset structure affects systemic risk. The differential effect of the asset structure on systemic risk is attributed to a signal of banks' future insolvency that investors receive at the intermediate date. When investors detect a signal of banks' future insolvency ${ }^{7}$, they do not roll over the short-term debt, forcing all banks into early liquidation of their assets. In this context, systemic risk in the banking system is due to the banks' failure to roll over their short-term debt.

In summary, theoretical and empirical evidence suggest that the level of systemic risk in the banking system increases with banks' rollover risk, indicating the contribution of bank funding maturity to a country's bank systemic risk.

\subsection{Related literature on corporate investment}

\footnotetext{
${ }^{7}$ An investor's decisions are influenced by (1) information contagion, where news regarding one financial firm's problem(s) is correlated with negative shocks at other financial institutions because they are exposed to common risk factors, or (2) counterparty contagion, where one financial firm's trouble directly causes other financial institutions' problems (see e.g., Helwege, 2010).
} 
A firm's investment and financing decisions are more likely to be intertwined. In one of earlier studies, Mauer and Triantis (1994) propose a dynamic model in which a firm has the flexibility to manage both investment and financing decisions over time. Childs et al. (2005) show that in a dynamic model with conflicts over investment policy (of the growth option) between debt holders and equity holders ${ }^{8}$, financial flexibility, which is the ability to adjust the debt level over time, tends to encourage the use of short-term debt, which mitigates the under- and over-investment incentives and hence increases firm value. In a recent study, Bolton et al. (2011) emphasize the important role of the marginal value of liquidity (cash and credit line) in a dynamic model of investment, financing, and risk management for firms with financial constraints. In addition, Hirth and Viswanatha (2011) show that the relation between liquidity (e.g., cash holdings) and investment is U-shaped for financially constrained firms.

The finance literature reveals the influence of financial market liquidity on a firm's behaviors. For example, Lemmon and Roberts (2010) show that in a sample of non-financial firms during the period 1986-1993, firms' investment and financing are affected by shocks to the supply of credit given that a fall in net debt issuance and a decline in net investment are almost in equal proportion, as substitution to bank debt and other sources of capital is limited. In addition, using a sample of firms in Europe during the 2008-2009 financial crisis, Campello et al. (2012) show that firms with relatively less restricted access to credit tend to draw less funds from their line of credit, relative to firms with more restricted access to credit, and also document that credit lines play an important role with respect to investments during the crisis.

\footnotetext{
${ }^{8}$ The conflicts arise when a growth option exercise decision to maximize the market value of equity is preferred to a decision to maximize the market value of the firm.
} 
In summary, prior studies show that financial markets conditions exert substantial influence on corporate investment and capital structure decisions.

\subsection{Theoretical model}

In this section, we present a simple two-period model of a bank's investment (i.e., with time $t=0,1$ and 2). $I$ denotes a bank's total investment. $I_{L}$ denotes a bank's long-term financing. $I_{S}$ denotes a bank's short-term financing. $r_{L}$ is the long-term interest rate or equity yield rate. $r_{S}$ is the short-term interest rate, whereas $r_{S C}$ is the short-term interest rate during a financial crisis period. $F(I)$ denotes a bank's gross profit realized at time $t=2 . \sigma\left(I_{S}\right)$ is a probability of a financial crisis during a period between times $t=0$ and $t=1$.

If the bank invests $I$ at time $t=0$, the bank receives gross profits $F(I)$ at time $t=2$. To this end, the bank finances its investment using a combination of short-term and long-term financing. Suppose that the bank's long-term financing $\left(I_{L}\right)$ is fixed, implying that the issue cost of equity and long-term bond is sufficiently high. However, the bank is not required to make any payment to long-term financing until time $t=2$. The bank raises the remaining amount $I-I_{L}=I_{S}$ by issuing the short-term debt. If the bank uses the short-term debt, it must rollover the short-term debt at time $t=1$; that is, that bank needs to make the interest payment $r_{S} I_{S}$ and raises $I_{S}$ at time $t=1$. If a financial crisis does not occur, the bank can finance this additional amount $\left(1+r_{S}\right) I_{S}$ by the normal short-term interest rate $r_{S}$. Thus, the bank pays $\left(1+r_{S}\right)\left(1+r_{S}\right) I_{S}=\left(1+r_{S}\right)^{2} I_{S}$ at time $t=2$. However, if a financial crisis occurs, the bank must raise this additional amount $\left(1+r_{S}\right) I_{S}$ by accepting capital injection by the financial regulator (e.g., the central bank), issuing short-term junk debts with a higher short-term 
interest rate $r_{S C}\left(\text { where } r_{S C}>r_{S}\right)^{9}$, or selling the assets. If the financial regulator does not bail out the bank and the bank does not sell its illiquid assets at potentially fire sale prices (see, for example, Diamond and Rajan (2011) regarding a more detailed discussion about fears of fire sales and liquidity shocks in the banking system), the bank must therefore pay $\left(1+r_{S C}\right)\left(1+r_{S}\right) I_{S}$ at time $t=2$.

To make the subsequent analysis meaningful, we impose the following assumptions.

Assumption 1: $F^{\prime}(I)>0$ and $F^{\prime \prime}(I)<0$.

Assumption 2: $\sigma^{\prime}\left(I_{S}\right)>0$.

Assumption 1 is the standard assumption about the production function. Assumption 2 implies that a probability of a financial crisis during a period between times $t=0$ and $t=1$ is larger if the bank issues more short-term debt to finance its investment (i.e. loans made to firms in our model). That is, Assumption 2 suggests that due to the presence of rollover risk of a bank, systemic risk of the banking system is larger when the bank's short-term financing is larger.

Similar to Diamond and Rajan (2005), we suppose that the bank's long-term financing $I_{L}$ is fixed and cannot demand payments at time $t=1$. We next discuss the optimal short-term financing decision of the bank. We begin with the benchmark case in which the probability of a financial crisis during a period between times $t=0$ and $t=1$ is independent of the bank's

\footnotetext{
${ }^{9}$ In this sense, the increase in the interest rate during a financial crisis that is due to the fact the bank might be willing to pay higher for new short-term deposits could be thought of as one of three predictions in Diamond and Rajan (2005) with respect to how the bank may response to a shortage of the aggregate liquidity at an interim date (i.e. time $t=1$ in our model).
} 
short-term financing amount, that is, $\sigma^{\prime}\left(I_{S}\right)=0$. Then, the bank's optimization problem is represented as follows.

$$
\begin{aligned}
& \operatorname{Max}_{I_{S}}(1-\sigma)\left\{F\left(I_{S}+I_{L}\right)-\left[r_{S}+\left(1+r_{S}\right)^{2}\right] I_{S}-r_{L} I_{L}\right\} \\
& +\sigma\left\{F\left(I_{S}+I_{L}\right)-\left[r_{S}+\left(1+r_{S C}\right)\left(1+r_{S}\right)\right] I_{S}-r_{L} I_{L}\right\} .
\end{aligned}
$$

Solving this problem, we obtain the following first-order condition with respect to $I_{S}$.

$$
F^{\prime}\left(I_{S}+I_{L}\right)=r_{S}+(1-\sigma)\left(1+r_{S}\right)^{2}+\sigma\left(1+r_{S C}\right)\left(1+r_{S}\right) \equiv \Phi .
$$

Thus,

$$
I=I_{S}+I_{L}=F^{\prime-1}(\Phi) .
$$

We next analyze a case in which the probability of a financial crisis during a period between times $t=0$ and $t=1$ is an increasing function of the bank's short-term financing amount, that is, $\sigma^{\prime}\left(I_{S}\right)>0$. Then we obtain the following first-order condition with respect to $I_{S} \cdot$

$$
F^{\prime}\left(I_{S}+I_{L}\right)=\Phi+\sigma^{\prime}\left(I_{S}\right)\left(\Pi_{N}-\Pi_{C}\right)
$$

where 


$$
\begin{gathered}
\Pi_{N} \equiv F\left(I_{S}+I_{L}\right)-\left[r_{S}+\left(1+r_{S}\right)^{2}\right] I_{S}-r_{L} I_{L}, \\
\Pi_{C} \equiv F\left(I_{S}+I_{L}\right)-\left[r_{S}+\left(1+r_{S C}\right)\left(1+r_{S}\right)\right] I_{S}-r_{L} I_{L} .
\end{gathered}
$$

Hence,

$$
F^{\prime}\left(I_{S}+I_{L}\right)=\Phi+\sigma^{\prime}\left(I_{S}\right)\left(1+r_{S}\right)\left(r_{S C}-r_{S}\right)>\Phi
$$

Comparing Equations (1) and (2) with $F^{\prime \prime}(I)<0$ from Assumption 1, we now show that the bank's total investment level when $\sigma^{\prime}\left(I_{S}\right)>0$ is smaller than that when $\sigma^{\prime}\left(I_{S}\right)=0$. Thus, if systemic risk of the banking system is positively related to the bank's short-term financing, the bank's total investment is smaller. This result means that if the bank ex ante attempts to reduce a probability of (1) facing a higher interest rate in the second period due to a financial crisis $^{10}$ and/or (2) failing to receive a bailout from the central bank, the bank will ex ante have to internalize these costs and lower its investment. However, if the bank ex ante expects to be bailed out by the central bank, the bank's total investment is not constrained by a positive probability of a financial crisis (for a more detailed discussion about collective moral hazard, maturity mismatch, and expectations of systemic bailouts by financial authorities, please see Farhi and Tirole (2012)).

In this model, there are three agents: bank depositors (hereafter "depositors"), commercial banks (hereafter "banks"), and firms in different industries (excluding the banking industry). Consistent with the financial intermediation literature as in Diamond and Rajan (2000) and

10 The higher short-term interest rate reflects higher risk premium, which would result in widening credit spreads. 
Diamond and Rajan (2005), we assume that depositors make a short-term (demand) deposit at one or more banks, given the market deposit interest rate $\left(r_{d e p}\right)$ prevailing at time $t=0$.

We have already discussed the financing problem of banks. The bank uses short-term financing (i.e., deposits) to invest in risky assets by lending to firms at the market lending interest rate $\left(r_{l}\right)$, conditioned on the risk profile of the firms, at time $t=0$. The bank may also want to diversify its portfolio of risky assets (e.g., making loans to firms in different industries) to reduce portfolio risk. If all banks diversify their portfolio, in equilibrium their portfolio tends to be identical. This asset commonality, together with the higher dependence on short-term financing, in turn gives rise to systemic risk.

A firm finances its investment using its initial equity (with an initial required rate of return on equity $\left(r_{e}\right)$ ) and a loan from a bank (with an initial cost of debt $=r_{d}=r_{l}$ ) at time $t=$ 0. In equilibrium, the firm chooses the amount of investments (and projects) whereby the marginal return on the investment equates its marginal cost (i.e. the weighted average marginal costs (WACC)) at time $t=0$. However, under the presence of asymmetric information between the bank and the firm, the firm may rationally overinvest whereby a "marginally" negative NPV project with a large positive return, which is known to the firm but is unknown to the bank, is undertaken and is financed by bank loans.

In policy terms, the model indicates that to ameliorate the positive impact of bank systemic risk on corporate investment, financial markets regulators and/or banking supervisory authorities should address the fundamental question of how to impose banks to internalize the costs of a financial crisis that is caused by a high degree of bank systemic risk contributed by each bank in the system. In our model, we show that a bank's investment is smaller when a probability of a financial crisis is positive. Therefore, we argue that banks are more inclined to internalize these costs when a probability of not being bailed out by the central bank during a financial crisis is sufficiently high; consequently, the level of bank 
systemic risk will be smaller. Overall, our arguments are generally resonant with those of Diamond and Rajan (2005) and of Farhi and Tirole (2012).

\subsection{Hypothesis development}

During periods of economic expansion and credit booms, firms are more likely to exhibit a higher degree of investment, as banks are willing to finance their investments. Given that all banks tend to use short-term financing and to hold an identical portfolio of loans, which is optimal to individual banks, the level of asset commonality amongst banks is therefore expected to increase the level of systemic risk in the banking system. As a result, variation of corporate investment is correlated with their investment opportunities and financial market conditions (e.g., credit booms) as well as with the level of bank systemic risk. However, in equilibrium, the effect of bank systemic risk on banks' investments (e.g., loans) and firms' investments depends on whether banks ex ante internalize the costs of potential financial crises.

In fact, it is widely known that moral hazard problems may arise when the agent's (in this paper, "managers") action is not verifiable, or when the agent receives private information after the relationship has been initiated (see Hart (1995) for the general agency problem and Diamond and Rajan (2000) for the agency problem of banks). In our paper, risk shifting is not verifiable from outside. If the authority bails out an insolvent bank in the financial distress and if many bank managers anticipate the bailout policy, many bank managers prefer more profitable but risky investments because their banks are bailed out even though their banks are insolvent as a result of their investment's failure. This moral hazard behavior of bank managers will increase in banks' investments, which encourage firms to invest more, thereby increasing the systematic risk and the likelihood of the financial crisis. Indeed, once 
many bank managers expect that the authority will not help their banks, their optimistic beliefs are converted into pessimistic ones. The banks' investments fall concurrently, which result in a fall in liquidity for firms. As a result, a financial crisis subsequently ensues from liquidity shocks to financial markets.

When the externality of bank systemic risk is not internalized, the influence of bank systemic risk on corporate investment, credit cycles, and business cycles is more likely to be substantial. However, once the externality of bank systemic risk is internalized, the bank's total investment may be reduced substantially, which leads to severe recessions. Evidence of banking crises, and especially, the global financial crisis of 2007-2008 points to the notion that collectively banks do not substantially internalize the cost of a financial crisis.

In Section 2.3, we develop a simple two-period model in which a bank's investment (e.g., loans) is associated with the degree of bank systemic risk that is driven by the excessive use of short-term financing and/or asset commonality across banks. We argue and show that banks tend to take on riskier loans, which lead to an increase in the supply of credit provided by the banking system. Subsequently, there is an increase in bank systemic risk that is more likely to cause firms to invest in riskier projects.

Building upon prior studies and above discussions, we argue that bank systemic risk positively affects firms' investment and that firms with more growth opportunities are more likely to invest more than those with less growth opportunities during periods of high degrees of bank systemic risk. Since bank systemic risk is a multi-dimensional construct, we therefore propose that different aspects of bank systemic risk are more likely to have different effects on corporate investment. More specifically, we expect that during period of high degrees of bank systemic risk in terms of bank funding maturity (i.e., short bank funding maturity), corporate investment should be high. That is, there is a negative association between bank funding maturity and corporate investment. Second, we expect bank system risk in terms of 
bank asset commonality to be associated with corporate investment. However, there is a question of whether the effect of bank asset commonality on corporate investment is positive or negative. On the one hand, the effect should be positive when a measure of bank asset commonality focuses on banks' loan portfolios. On the other hand, when one measures bank asset commonality by focusing on banks' revenue structure (e.g., from core banking activities such as interest-income-generating assets versus from non-core banking activities such as non-interest-income generating assets), the effect is ambiguous. If the similarity in banks' asset structure with respect to revenue structure leads to the increase (decrease) in loan supply, the effect is positive (negative).

In sum, we propose the following testable hypotheses:

Hypothesis 1: There is a positive relationship between bank systemic risk and corporate investment.

Hypothesis 1A: There is a positive relationship between short-term bank funding (i.e., the proportion of short-term funding to long-term funding) and corporate investment. More specifically, corporate investment is high (low) during periods of a large (small) share of short-term bank funding.

Hypothesis 1B: There is a positive relationship between bank asset commonality and corporate investment. More specifically, corporate investment is high (low) during periods of high (low) bank asset commonality.

\section{Data and methodology}

\subsection{Data and sample construction}


Our initial sample comprises 2,552 publicly listed non-financial firms in the United States over the period 1991-2013 with special emphasis on the potential effect of the global financial crisis of 2007-2008 on the relation between systemic risk and corporate investment. The initial sample includes all non-financial firms ${ }^{11}$ that are listed from January 1, 1991 to December 31, 2013, excluding all IPOs during January 1, 2011 and December 31, 2013. This selection procedure ensures that firms included in our sample have a minimum of three-year observations required for regression analyses. We retrieve financial data on banks and firms from Datastream. To compute values for our bank systemic risk variables for the United States in our study, we similarly construct our sample of 378 publicly listed banks using a similar procedure.

\subsection{Key variables}

There are several ways of measuring bank systemic risk. Our primary measures of bank systemic risk is based on the work of Allen et al. (2012a). That is, the degree of bank systemic risk can be measured by using two proxies: (1) the debt maturity of banks and (2) the clustered asset structure of banks. The main idea is that the use of short-term debt by banks may increase the information contagion in the event of a run on one bank. When banks have the identical composition of the asset structure, an adverse shock to one bank (e.g., unfavorable information about one bank) might be interpreted as a signal of potential adverse shocks to all other banks in the system due to the similarity in the asset structure.

We use the cross-sectional average debt maturity of banks as our first measure of systemic risk (SYSRISK1). A high value of SYSRISK1 implies the shorter debt maturity,

\footnotetext{
${ }^{11}$ We exclude firms classified in the following industries: banks, financial services, life insurance, non-life insurance, and unclassified industries, according to the industry classification of Datastream.
} 
which indicates a high level of bank systemic risk due to rollover risk of the banks. The debt maturity, measured as the ratio of short-term debt to long-term debt ${ }^{12}$, indicates how banks finance their assets. The high proportion of the short-term debt to total debt increases a bank's rollover risk attributable to the shorter debt maturity (in additional to the bank's rollover risk due to deposits).

To measure the level of clustered asset structure (or asset commonality) of banks, we use two variables. Following the work of Calmès and Théoret (2014), we use (1) the inverse of the cross-sectional standard deviation of the share of total loans to total assets, which is denoted SYSRISK2, and (2) the inverse of the cross-sectional standard deviation of a share of non-interest income to net revenue, which is denoted SYSRISK3. The basic idea is that when banks mimic their peers' asset portfolio (e.g., loans), variation in the ratio of loans to assets becomes smaller, and hence, the standard deviation of the ratio of loan to assets is small, which implies that bank systemic risk is high. For ease of interpretation, we use the inverse of the cross-sectional standard deviation so that a high value of SYSRISK2 or SYSRISK3 corresponds to a higher level of bank systemic risk. ${ }^{13}$

In the robustness section, we alternatively use (1) Z-Score and (2) the ratio of nonperforming loan to total loans ratio (NPLTL) as our measures of bank systemic risk to test the robustness of our results.

Following prior studies, such as Denis and Sibilkov (2010), Julio and Yook (2012) and Foucault and Fresard (2014), we measure a firm's investment as the ratio of capital

\footnotetext{
${ }^{12}$ Deposits are not included in both short-term and long-term debt.

${ }^{13}$ While we also consider the use of the level of clustered asset structure by using the cross-sectional standard deviation of (1) Commercial \& Industrial Loans/Assets, (2) Consumer Loans/Assets, or (3) Agricultural Loans/Assets, we find that the required availability of these time series variables are limited prior to 2000. Therefore, we do not use them.
} 
expenditure to one-period lagged total assets. Similar to prior studies such as Aivazian et al. (2005) and Denis and Sibilkov (2010), we include a number of firm-level variables to control for factors that have been found to affect corporate investment. Firm size is measured as the natural logarithm of real total assets in million US dollars. We deflate the book value of total assets in USD by US CPI (CPI = 100 in 2010). Leverage (LEV) is computed as the ratio of total debt to total assets. Cash/Assets (CASHTA) is the ratio of cash to total assets. Current Assets/Current Liabilities (CACL) is the ratio of current assets to current liabilities. Marketto-book ratio (MBV), computed as the ratio of the market value of equity to the book value of equity, is used as a proxy for a firm's investment or growth opportunities. Return on Assets (ROA) is measured as the ratio of EBIT to total assets.

To control for country-level time-varying economic conditions that may affect firms' investment, we include GDP growth, export intensity (measured as the natural logarithm of the percentage share of export to GDP), stock market return (measured as the first difference in the natural logarithm of the stock market index) $)^{14}$, banking sector development (measured as the natural logarithm of the percentage share of domestic credit to private sector by banks to GDP) in all regressions. To control for the availability of bank loans in the system, we include two indicators: (1) LOANTA, which is the cross-sectional average ratio of total loans to assets of banks in the sample, and (2) SNONINT, which is the cross-sectional average share of non-interest income as a percent of net revenue of banks in the sample.

\subsection{Empirical Approach: Panel OLS estimations of investment}

\footnotetext{
${ }^{14}$ More specifically, we use the S\&P 500 index to compute the annual stock returns for the United States.
} 
We test our prediction that bank systemic risk is positively associated with corporate investment by estimating a series of the following panel OLS regressions of the investment rate on measures of bank systemic risk:

$$
\begin{gathered}
\operatorname{CAPEXTA}_{i, j, t} \equiv \frac{\operatorname{CAPEX}_{i, j, t}}{T A_{i, j, t-1}}=b_{0}+b_{1} \operatorname{RISK}_{t-1}+\delta \mathbf{F C O N}_{i, j, t-1}+\gamma \mathbf{C C O N}_{t-1}+u_{i}+\varepsilon_{i, j, t}, \\
\operatorname{CAPEXTA}_{i, j, t} \equiv \frac{\operatorname{CAPEX}_{i, j, t}}{T A_{i, j, t-1}}=b_{0}+b_{1} \operatorname{RISK}_{t-1}+\delta \mathbf{F C O N}_{i, j, t-1}+\gamma \mathbf{C C O N}_{t-1}+v_{i}+\varepsilon_{i, j, t},
\end{gathered}
$$

where $i, j, t$ index firm, industry, and year, respectively. $C A P E X T A_{i, j, t}$ denotes the investment rate of firm $i$ in industry $j$ at time $t$, which is defined as the ratio of investment rate (CAPEX) to one-period lagged total assets $(T A)$. We empirically compute the investment rate $(C A P E X T A)$ as the natural logarithm of the ratio of investment $\left(C A P E X_{i, j, t}\right)$ to one-period lagged total assets $\left(T A_{i, j, t-1}\right)$. In order to control for endogeneity and to establish causality, all right-hand variables are one-period lagged. $R I S K_{t-l}$ denotes bank systemic risk variable for at time $t-1 . \mathbf{F C O N}_{i, j, t}$ is a vector of firm-level control variables at time $t-1 ; \mathbf{C C O N}_{t-1}$ is a vector of country-level control variables at time $t-1 ; u_{i}$ are firm-fixed effects; and $v_{t}$ are industryfixed effects. In terms of inference, the estimate of the effect of bank systemic risk on corporate investment obtained from panel OLS regressions (e.g., Regressions (3) and (4)) is unbiased when the measure of bank systemic risk is uncorrelated with other determinants of corporate investment.

Since a bank's behaviors might be driven by macro-level conditions that also affect a firm's investment, as a robustness check, we alternatively use bank systemic risk measures that are not related to macro-level factors that also affect a firm's investment opportunities and investment decisions. More specifically, we use a two-step regression approach. In the 
first step, I regress each of the bank systemic risk measures on macro-level variables as follows:

$$
R I S K_{t}=b_{0}+b_{1} G D P_{t}+b_{2} E X P O R T_{t}+b_{3} T_{E R M_{t}}+\varepsilon_{t}
$$

where $t$ indexes time, RISK denotes bank systemic risk variable, GDP denotes GDP growth (in \%), LNEXPORT denotes export intensity (measured as the natural logarithm of the percentage share of export to GDP), and TERM denotes the term spread (measured as the difference in yield on 10-year zero-coupon US government bond and yield on 1-year zerocoupon US government bond). Residuals from Equation (5), which are orthogonal to the macro-level variables, are used as the measure of bank systemic risk in the second-stage regression.

We include firm fixed effects in panel OLS regressions to control for any unobserved time invariant firm-level effects. Essentially, when firm fixed effects are included in the regression, we look at the effect of variation in bank systemic risk over time on variation in corporate investment over time. As a robustness check, we replace firm fixed effects with industry fixed effects to control for unobserved time invariant industry-level effects at the industry level. ${ }^{15}$ For all estimations, standard errors are robust to heteroskedasticity and serial correlation and are clustered at the firm level.

\section{Empirical results}

\footnotetext{
15 Industry dummies are based on the Level 2 (28 business sectors) classification of the Thomson Reuters Business Classification system.
} 


\subsection{Descriptive statistics}

Table 1 reports descriptive statistics for key country-level variables. Since all of the bank systemic risk variables (as well as all other country-level variables) are stationary, we consider them in levels, rather than in first differences. In subsequent sections, we will use both the basic measures of bank systemic risk (i.e., SYSRISK1, SYSRISK2, and SYSRISK3) as well as the alternative measures of bank systemic risk. While SYSRISK1 is not correlated with SYSRISK2, it is highly correlated with SYSRISK3. These results appear to suggest that some banks might mimic others' funding strategies and non-interest income strategies, causing the two measures to be highly correlated.

\section{[INSERT TABLE 1 ABOUT HERE] \\ [INSERT TABLE 2 ABOUT HERE] \\ [INSERT TABLE 3 ABOUT HERE]}

Consistent with the literature, we winsorize all firm-level variables at the $1 \%$ and $99 \%$ levels in order to reduce the effect of outliers. Table 2 reports summary statistics for all firmlevel variables for a final sample of 36,136 firm-year observations. Panel A of Table 2 provides summary statistics for all firms in the full sample, while Panels B and C of Table 2 report summary statistics for large firm and small firm subsamples, respectively. Large firms are defined as observations with the value of real total assets larger than the cross-sectional median value of real total assets at the country level. Compared to large firms, small firms perform poorer on average (the mean value of ROA for small firms is $-3.38 \%$; the mean value of ROA for large firms is $8.90 \%$ ) and have lower leverage (the mean value of LEV for small firms is $15.89 \%$; the mean value of LEV for large firms is $28.32 \%$ ). 
Table 3 presents correlation coefficients for the firm-level variables. Correlation coefficients for all explanatory variables are generally below 0.40 (however, the correlation between CASHTA and CATA are about 0.64$)^{16}$; therefore, multicollinearity is not of great concern in our study. ${ }^{17} \mathrm{We}$ are thus confident that using a full set of firm-level control variables (excluding CATA) should not result in a serious multicollinearity problem.

\subsection{The effect of bank systemic risk on corporate investment: OLS regressions}

Table 4 displays the panel OLS regression estimation results of Equations (1) and (2). In column (1) of Table 4, we regress the investment rate, which is computed as CAPEXTA, on a full set of firm-level and country-level control variables, without fixed effects, for a full sample. The sign of the estimated coefficients is generally consistent with the literature. For instance, the positive and significant estimated coefficients on the market-to-book-value ratio (MBV) and the return on asset ratio (ROA) imply that firms with more investment opportunities and good operating performance, respectively, tend to invest more. The negative and significant coefficient on the leverage ratio (LEV) means that firms with higher leverage tend to invest less because they are financially constrained. Consistent with our expectation and prior empirical evidence (see e.g., Billett et al., 2011; Julio and Yook, 2012), the coefficient on $\Delta \mathrm{GDP}$, which is GDP growth, is positive and statistically significant, thereby suggesting that firms tend to invest more during periods of economic expansion. Interestingly, the coefficient on MKTRETURN is negative and statistically significant,

\footnotetext{
${ }^{16}$ Given that CASHTA and CATA are highly correlated, we do not include CATA in the regression.

${ }^{17}$ Low correlations among the right-hand side variables means that the efficiency of the estimation of the fixedeffects model is less likely to be affected by the low correlations between the explanatory variables.
} 
suggesting that firms invest less following stock market booms. The results also show that LOANTA and SNONINT have a negative effect on the investment rate.

\section{[INSERT TABLE 4 ABOUT HERE]}

In column (2), we add firm fixed effects in our baseline regression. ${ }^{18}$ The adjusted $R^{2}$ of the model increases from 0.163 to 0.618 . The sign and significance level of the variables in the model is generally unchanged. The coefficient on four of the six country-level variables remains statistically significant.

To test the effect of bank systemic risk on corporate investment, we sequentially add SYSRISK1, SYSRISK2, and SYSRISK3 in columns (3), (4) and (5) of Table 4. We do so because SYSRISK1 and SYSRISK3 are highly correlated $(r=0.52)$. The estimated coefficient on SYSRISK1 in column (3) is positive and statistically significant, indicating that corporate investment increases as bank funding maturity (measured as the cross-sectional average ratio of short-term debt to long-term debt of banks) becomes shorter. In other words, when the proportion of short-term funding to long-term funding increases, there is an increase in corporate investment. This finding provides empirical support to Hypothesis 1A.

The coefficient on SYSRISK2 in column (4) is negative and statistically insignificant. Hence, the degree of bank systemic risk, measured as the inverse of the cross-sectional standard deviation of the ratio of total loans to total assets, is not associated with corporate investment. We interpret this finding as empirical evidence to suggest that when banks mimic their peers' lending behaviors, thereby increasing the degree of similarity with respect to the loan ratio, corporate investment does not change. It is important to note that SYSRISK2 can

\footnotetext{
${ }^{18}$ We conduct Hausman-tests to compare the random and fixed effects estimation. Results suggest that the fixed-effects models are preferred.
} 
be high at different levels of the loan ratio (e.g., it can be high when many bank have a high ratio of total loans to total assets or when many banks have a low ratio of total assets). Therefore, a high value of SYSRISK2 does not indicate that many banks lend more to firms. As a consequence, the insignificant coefficient on SYSRISK2 cannot indicate whether or not banks' lending decisions affect corporate investment. Nevertheless, the coefficient on LOANTA directly captures the extent to which the banking system lends affects corporate investment.

The coefficient on SYSRISK3 in column (5) is positive and statistically significant, implying that variation in bank systemic risk regarding non-traditional banking activities is positively associated with corporate investment. Taken together, the results of columns (4) and (5) provide some empirical evidence for Hypothesis $1 \mathrm{~B}$ that predicts the positive relationship between bank asset commonality and corporate investment. In a related study, Paltalidis et al. (2015) use a network structure approach to show that the interconnectedness in the banking network contributes to systemic risk of banks in 16 Eurozone countries.

Overall, empirical evidence reported in Table 4 suggest that there is a significant and positive association between bank systemic risk and corporate investment, after controlling for a large set of firm-level and country-level variables and thus provide empirical support to Hypothesis 1, which predicts that variation in corporate investment can be explained by bank systemic risk. It is important to note that while bank system risk has the positive effect on corporate investment, adding the bank systemic risk variables in the models does not substantially improve the explanatory power (e.g., the adjusted $R^{2}$ ) of the models (see columns (4) through (5)).

\subsection{The effect of bank systemic risk on corporate investment: Two-stage OLS regressions}


As discussed earlier, there are concerns that the bank systemic risk measures might be driven by other factors that also affect firms' investment, leading to endogeneity concerns. We address this issue by using a two-step panel OLS regression approach. In the first step, we estimate time-series regressions of Equation (5), where the dependent variable is SYSRISK1, SYSRISK2, and SYSRISK3. We use the residuals obtained from the regression, which are orthogonal to the macro-level variables and capture innovations or shocks to systematic risk, as the alternative measure of bank systemic risk in the second-stage OLS regression. BSR1, BSR2, and BSR3 are the residuals obtained from the regression of Equation (5) where the dependent variable is SYSRISK1, SYSRISK2, and SYSRISK3, respectively. We report the first-stage regression results in Table 5, which show that in general, our main bank systemic risk measures are not contemporaneously associated with GDP growth, export intensity, and the term spread. These results provide supporting evidence to suggest that our bank systemic risk measures are generally not driven by macroeconomic conditions.

\section{[INSERT TABLE 5 ABOUT HERE]}

Table 6 reports the second-stage OLS regression results. Since it has been well documented in the literature, as noted by Eberly et al. (2012), that lagged investment is the best predictor of current investment at the firm level, we add a one-period lagged dependent variable into our second-stage OLS regressions (see columns (4) through (6)). Overall, the results are largely unchanged. More specifically, the coefficient on BSR1 (see column (1) and (4)) remains positive and statistically significant, suggesting that that innovations in bank systemic risk with respect to bank funding maturity have a positive effect on corporate investment. The findings provide support for Hypothesis 1A. We still find that BSR2 is not associated with the investment rate (see columns (2) and (5)). The results show that BSR3 is 
positively associated with corporate investment in the dynamic OLS regression (see column (6)). These results suggest that the relationship between bank asset commonality and corporate investment is positive but not robust, thereby provide only partial support for Hypothesis 1B. It is important to note that BSR1, BSR2, and BSR2 essentially measure excess bank systemic risk or shocks to bank systematic risk. Therefore, the results of the twostage OLS regressions provide some empirical evidence for the effect of excess bank systemic risk on corporate investment.

\section{[INSERT TABLE 6 ABOUT HERE]}

Overall, the results from panel OLS regressions in Section 4.2 as well as two-stage panel OLS regressions in this section show that our bank systemic risk measure that captures "bank funding maturity" is positively associated with corporate investment and is robust to different estimation approaches. However, the positive association between bank asset commonality and corporate investment is not robust.

\subsection{Interaction effects of bank systemic risk and firm characteristics}

Thus far, we show that bank systemic risk is positively associated with corporate investment. In this section, we examine whether the effect of bank systemic risk on corporate investment is asymmetric with respect to firm characteristics. For instance, compared with firms with high leverage that are more likely to be financially constrained, firms with lower leverage should be less sensitive to bank systematic risk. In particular, we are interested in how larger firms as well as firms with better investment opportunities, high leverage, and/or 
good operating performance react to variation in bank systemic risk in terms of bank funding maturity (SYSRISK1).

\section{[INSERT TABLE 7 ABOUT HERE]}

Table 7 reports the results of second-stage regressions using the investment rate as the dependent variable. In column (1) of Table 7, we interact BSR1 with LEV and find that the coefficient on the interaction term is positive and statistically significant, suggesting that the positive effect of bank systemic risk on corporate investment is stronger for firms with higher leverage. In column (2), we interact BSR1 with MBV and find that the coefficient on the interaction term is positive but statistically insignificant, suggesting that investment opportunities do not moderate the relationship between bank systemic risk and corporate investment. In column (3) and (4), we interact BSR1 with LARGE, which is a dummy variable that takes a value of one for observations with the value of real total assets larger than the cross-sectional median value of real total assets and zero otherwise, and LNTA, respectively. Results show that firm size does not moderate the effect of bank systemic risk on corporate investment. In column (5), we interact BSR1 with ROA to test the moderating effect of firm performance. As the coefficient on the interaction term between BSR1 and ROA is statistically significant only at the $10 \%$ level, there is no evidence to suggest that the effect of bank systemic risk on corporate investment is sensitive to firm size.

In summary, the findings in this section suggest that firms with higher financial leverage are more sensitive to the influence of bank systemic risk on corporate investment. One plausible explanation is that firms with higher leverage are financially constrained and thus have better incentives to invest more during period of high levels of bank systemic risk (i.e. bank funding maturity) because banks are more willing to take on riskier investments. On the 
other hand, firms with low leverage (or no debt) are less dependent on banks to finance their investment. We find that there is no empirical evidence to suggest that firm size, operating performance, and investment opportunities moderate the effect of bank systemic risk on corporate investment.

\subsection{Robustness checks}

\subsubsection{The non-linear effect of bank systemic risk}

To check for the non-linear effect of bank systemic risk on corporate investment, we add a squared term of the bank systemic risk variables in our baseline specification of the secondstage OLS regression. The (untabulated) results provide no evidence for the non-linear influence of bank systemic risk on corporate investment. These results are inconsistent view the view that the relationship between the chosen debt maturity and credit quality is nonmonotonic (see e.g., Diamond, 1991). In our case, the debt maturity structure is measured as SYSRISK1 or BSR1, while the credit quality is largely driven by the quality of bank loans, which is unfortunately unobservable in our data set.

\subsubsection{Do bank systemic risk measures pick up reflect other risk factors?}

In this subsection, we address potential concerns whether our bank systemic risk measures simply reflect other macro-economic conditions and/or market fear. During periods of low levels of market fear, firms are more willing to make additional investments, while during periods of high levels of market fear, firms are more likely to be more risk averse and thus cut back on investments. In the main analysis, our two-stage panel OLS regression 
approach partially address this issue. That is, in the first-stage regression, we control for the contemporaneous influence of GDP growth, export intensity, and the term spread.

We additionally test whether our main findings remain robust after controlling for risk premium (measured as prime rate minus T-bill rate), which is considered as a rough proxy for market fear. Table 8 presents the panel OLS regression results of the additional tests using the investment rate as the depending variable. As can be seen, SYSRISK1 still has the positive effect on corporate investment after additionally controlling for risk premium.

\section{[INSERT TABLE 8 ABOUT HERE]}

\subsubsection{Alternative measures of bank systemic risk}

We additionally check whether our results are driven by our measures of systemic risk. More specifically, we use two alternative measures of bank systemic risk: (1) Z-score (ZSCORE), which has been used widely to measure banking stability or bank insolvency risk $^{19}$, and (2) the ratio of non-performing loan to total loans ratio (NPLTL) ${ }^{20}$. We estimate our dynamic OLS regressions again and find that the pattern of our results is qualitatively unchanged. For instance, the positive effect of SYSRISK1 remains evident after controlling

\footnotetext{
${ }^{19}$ We obtain ZSCORE, which is computed as the sum of the return on assets plus the capital-asset ratio divided by the standard deviation of the returns on assets, from the Global Financial Development Database of the World Bank. We use the natural logarithm of ZSCORE to make the variable normally distributed.

${ }^{20}$ Čihák and Schaeck (2010) show that non-performing loans can measure the banking system’s vulnerabilities. As with the estimation of our bank systemic risk measures, we compute the average NPLTL ratio based on our sample of 378 publicly listed banks. NPLTL is highly correlated with SYSRISK1 and SYSRISK2.
} 
for ZSCORE or NPLTL. It should be noted that both Z-score and NPLTL have a positive effect on corporate investment.

\section{Discussion}

Thus far, we theoretically argue and provide empirical evidence for the positive impact of bank systemic risk on corporate investment. More precisely, we show that the degree of bank systemic risk with respect to bank funding maturity is positively associated with corporate investment. In addition, we document that the degree of bank systemic risk with respect to bank asset commonality is positively associated with corporate investment. Our findings provide additional support the view that systematic risk in the financial/banking systems drives corporate investment, which in turn affects the economy (see e.g., Allen et al., 2012b; Gersbach and Rochet, 2012; Giglio et al., 2016).

Our paper connects two related streams of research by making a link between a countrylevel measure of bank systemic risk and firm-level investment. Scholars in the are of bank systemic risk have emphasized the importance of systemic risk and put forth the idea that there is a need for using a macroprudential approach to managing banking risk (Arnold et al., 2012; Gauthier et al., 2012). We show that bank systemic risk plays an important role in affecting corporate investment, given that the influence of bank systemic risk still exists even after controlling for the supply of bank loans, measured as the loan-to-asset rate. This finding is important because it shows that the supply of bank loans and bank systemic risk are different and both affect corporate investment.

Our findings complement prior studies in corporate finance (see e.g., Denis and Sibilkov, 2010; Hackbarth and Mauer, 2012; Julio and Yook, 2012; Panousi and Papanikolaou, 2012; Titman, 2013) by showing that after controlling for a large set of macro-level factors, several 
firm-level factors (e.g., firm size, liquidity, MBV, leverage, and profitability) still affect corporate investment. However, we show that cash holdings and dividends have lost their influence on corporate investment after controlling for bank systemic risk measures, raising a question of the effects of cash holdings and dividends on corporate investment, which have been documented in the literature.

\section{Conclusion}

In this paper, we make a simple point that variation in corporate investment can be explained by bank systemic risk. Using a sample of publicly listed firms in the US over the period 1991-2013, we consistently show that an increase in bank systemic risk based on bank funding maturity is positively associated with corporate investment. Our results are consistent with prior literature that predicts the positive relationship between the degree of systemic risk in the banking sector and corporate investment. In addition, we find that the positive effect of bank funding maturity on corporate investment is stronger for firms with higher financial leverage. We also document the positive relationship between bank systemic risk based on bank asset commonality and corporate investment; however, this result is not robust.

Our results have important implications for banking supervisory authorities and/or financial markets regulators. As we conclude that variation in bank systemic risk positively affects corporate investment, after controlling for a number of firm- and country-level factors, it is clear that the level of bank systemic risk can generate substantial business cycles by encouraging firms to invest more. Since this study mainly focuses on the impact of bank systemic risk on corporate investment the US, we hope that future research would shed light on the influence of bank systemic risk on corporate investment in other countries. 


\section{References}

Acharya, V.V., Gale, D., Yorulmazer, T., 2011. Rollover risk and market freezes. Journal of Finance 66, 1177-1209.

Aivazian, V.A., Ge, Y., Qiu, J., 2005. The impact of leverage on firm investment: Canadian evidence. Journal of Corporate Finance 11, 277-291.

Allen, F., Babus, A., Carletti, E., 2012a. Asset commonality, debt maturity and systemic risk. Journal of Financial Economics 104, 519-534.

Allen, L., Bali, T.G., Tang, Y., 2012b. Does systemic risk in the financial sector predict future economic downturns? Review of Financial Studies 25, 3000-3036.

Anginer, D., Demirguc-Kunt, A., Zhu, M., 2014. How does competition affect bank systemic risk? Journal of Financial Intermediation 23, 1-26.

Arnold, B., Borio, C., Ellis, L., Moshirian, F., 2012. Systemic risk, macroprudential policy frameworks, monitoring financial systems and the evolution of capital adequacy. Journal of Banking \& Finance 36, 3125-3132.

Bedendo, M., Bruno, B., 2012. Credit risk transfer in U.S. commercial banks: What changed during the 2007-2009 crisis? Journal of Banking \& Finance 36, 3260-3273.

Bernal, O., Gnabo, J.-Y., Guilmin, G., 2014. Assessing the contribution of banks, insurance and other financial services to systemic risk. Journal of Banking \& Finance 47, 270287.

Bianchi, J., 2011. Overborrowing and systemic externalities in the business cycle. American Economic Review 101, 3400-3426.

Billett, M.T., Garfinkel, J.A., Jiang, Y., 2011. The influence of governance on investment: Evidence from a hazard model. Journal of Financial Economics 102, 643-670. 
Billio, M., Getmansky, M., Lo, A.W., Pelizzon, L., 2012. Econometric measures of connectedness and systemic risk in the finance and insurance sectors. Journal of Financial Economics 104, 535-559.

Bolton, P., Chen, H.U.I., Wang, N., 2011. A unified theory of Tobin's q, corporate investment, financing, and risk management. Journal of Finance 66, 1545-1578.

Calmès, C., Théoret, R., 2014. Bank systemic risk and macroeconomic shocks: Canadian and U.S. evidence. Journal of Banking \& Finance 40, 388-402.

Campello, M., Giambona, E., Graham, J.R., Harvey, C.R., 2012. Access to liquidity and corporate investment in Europe during the financial crisis. Review of Finance 16, 323-346.

Childs, P.D., Mauer, D.C., Ott, S.H., 2005. Interactions of corporate financing and investment decisions: The effects of agency conflicts. Journal of Financial Economics $76,667-690$.

Čihák, M., Schaeck, K., 2010. How well do aggregate prudential ratios identify banking system problems? Journal of Financial Stability 6, 130-144.

Cohen, L.J., Cornett, M.M., Marcus, A.J., Tehranian, H., 2014. Bank earnings management and tail risk during the financial crisis. Journal of Money, Credit and Banking 46, 171-197.

Cubillas, E., González, F., 2014. Financial liberalization and bank risk-taking: International evidence. Journal of Financial Stability 11, 32-48.

De Jonghe, O., Diepstraten, M., Schepens, G., 2015. Banks' size, scope and systemic risk: What role for conflicts of interest? Journal of Banking \& Finance 61, Supplement 1, S3-S13.

Demirgüç-Kunt, A., Huizinga, H., 2010. Bank activity and funding strategies: The impact on risk and returns. Journal of Financial Economics 98, 626-650. 
Denis, D.J., Sibilkov, V., 2010. Financial constraints, investment, and the value of cash holdings. Review of Financial Studies 23, 247-269.

Diamond, D.W., 1991. Debt maturity structure and liquidity risk. Quarterly Journal of Economics 106, 709-737.

Diamond, D.W., Rajan, R.G., 2000. A theory of bank capital. Journal of Finance 55, 24312465.

Diamond, D.W., Rajan, R.G., 2005. Liquidity shortages and banking crises. Journal of Finance 60, 615-647.

Diamond, D.W., Rajan, R.G., 2011. Fear of fire sales, illiquidity seeking, and credit freezes. Quarterly Journal of Economics 126, 557-591.

Duran, M.A., Lozano-Vivas, A., 2014. Risk shifting in the US banking system: An empirical analysis. Journal of Financial Stability 13, 64-74.

Eberly, J., Rebelo, S., Vincent, N., 2012. What explains the lagged-investment effect? Journal of Monetary Economics 59, 370-380.

Farhi, E., Tirole, J., 2012. Collective moral hazard, maturity mismatch, and systemic bailouts. American Economic Review 102, 60-93.

Foucault, T., Fresard, L., 2014. Learning from peers' stock prices and corporate investment. Journal of Financial Economics 111, 554-577.

Gauthier, C., Lehar, A., Souissi, M., 2012. Macroprudential capital requirements and systemic risk. Journal of Financial Intermediation 21, 594-618.

Gersbach, H., Rochet, J.-C., 2012. Aggregate investment externalities and macroprudential regulation. Journal of Money, Credit and Banking 44, 73-109.

Giglio, S., Kelly, B., Pruitt, S., 2016. Systemic risk and the macroeconomy: An empirical evaluation. Journal of Financial Economics 119, 457-471. 
Hackbarth, D., Mauer, D.C., 2012. Optimal priority structure, capital structure, and investment. Review of Financial Studies 25, 747-796.

Hart, O.D., 1995. Firms, contracts, and financial structure. Clarendon, Oxford.

He, Z., Xiong, W.E.I., 2012. Rollover risk and credit risk. Journal of Finance 67, 391-430.

Helwege, J., 2010. Financial firm bankruptcy and systemic risk. Journal of International Financial Markets, Institutions and Money 20, 1-12.

Hirth, S., Viswanatha, M., 2011. Financing constraints, cash-flow risk, and corporate investment. Journal of Corporate Finance 17, 1496-1509.

Iyer, R., Peydró, J.-L., da-Rocha-Lopes, S., Schoar, A., 2014. Interbank liquidity crunch and the firm credit crunch: Evidence from the 2007-2009 crisis. Review of Financial Studies 27, 347-372.

Jovanovic, B., Rousseau, P.L., 2014. Extensive and intensive investment over the business cycle. Journal of Political Economy 122, 863-908.

Julio, B., Yook, Y., 2012. Political uncertainty and corporate investment cycles. Journal of Finance 67, 45-84.

Lemmon, M., Roberts, M.R., 2010. The response of corporate financing and investment to changes in the supply of credit. Journal of Financial and Quantitative Analysis 45, $555-587$.

Leth-Petersen, S., 2010. Intertemporal consumption and credit constraints: Does total expenditure respond to an exogenous shock to credit? American Economic Review 100, 1080-1103.

Levine, R., Zervos, S., 1998. Stock markets, banks, and economic growth. American Economic Review 88, 537-558. 
López-Espinosa, G., Moreno, A., Rubia, A., Valderrama, L., 2012. Short-term wholesale funding and systemic risk: A global CoVaR approach. Journal of Banking \& Finance $36,3150-3162$.

Lorenzoni, G., 2008. Inefficient credit booms. The Review of Economic Studies 75, 809-833.

Mauer, D.C., Triantis, A.J., 1994. Interactions of corporate financing and investment decisions: A dynamic framework. Journal of Finance 49, 1253-1277.

Myers, S.C., 1977. Determinants of corporate borrowing. Journal of Financial Economics 5, 147-175.

Paltalidis, N., Gounopoulos, D., Kizys, R., Koutelidakis, Y., 2015. Transmission channels of systemic risk and contagion in the European financial network. Journal of Banking \& Finance 61, Supplement 1, S36-S52.

Panousi, V., Papanikolaou, D., 2012. Investment, idiosyncratic risk, and ownership. Journal of Finance 67, 1113-1148.

Schotter, A., Yorulmazer, T., 2009. On the dynamics and severity of bank runs: An experimental study. Journal of Financial Intermediation 18, 217-241.

Stulz, R., 1990. Managerial discretion and optimal financing policies. Journal of Financial Economics 26, 3-27.

Titman, S., 2013. Financial markets and investment externalities. Journal of Finance 68, 1307-1329.

Uhde, A., Michalak, T.C., 2010. Securitization and systematic risk in European banking: Empirical evidence. Journal of Banking \& Finance 34, 3061-3077. 
Table 1 Descriptive statistics for country-level variables during 1991-2013.

Bank Systemic Risk 1 (SYSRISK1) is defined as the cross-sectional mean of the share of short-term debt as \% of long-term debt of publicly listed banks in a country. Bank Systemic Risk 2 (SYSRISK2) is defined as the inverse of the cross-sectional standard deviation of the ratio of loan to assets (in \%) of publicly listed banks. Bank Systemic Risk 3 (SYSRISK3) is defined as the inverse of the cross-sectional deviation of the share of non-interest income as $\%$ of net revenue of publicly listed banks. SYSRISK1, SYSRISK2, AND SYSRISK3 are computed from a sample of 378 publicly listed banks in the US. $\triangle$ GDP denotes the GDP growth rate (in \%); LNBSD is the natural logarithm of the percentage share of domestic credit to private sector by banks to GDP. LNEXPORT is the natural logarithm of the percentage share of export to GDP; MKTRETURN denotes stock market return (in \%), measured as the first difference in the natural logarithm of the stock market index; LOANTA is the average ratio of total loans to assets of banks in a country; SNONINT is the average share of non-interest income to net revenue of banks in a country. TERM denotes term spread, which is measured as the difference in the yield on 10-year US government bond and the yield on 1-year US government bond. $N=23$

\begin{tabular}{lrrrrr}
\hline & Mean & Median & S.D. & Minimum & Maximum \\
\hline SYSRISK1 & 9.94 & 7.68 & 7.36 & 1.68 & 28.32 \\
SYSRISK2 & 0.08 & 0.08 & 0.01 & 0.07 & 0.09 \\
SYSRISK3 & 0.12 & 0.11 & 0.03 & 0.06 & 0.18 \\
$\Delta$ GDP & 2.51 & 2.75 & 1.79 & -2.80 & 4.85 \\
LNBSD & 3.91 & 3.91 & 0.09 & 3.79 & 4.09 \\
LNEXPORT & 2.37 & 2.36 & 0.12 & 2.20 & 2.60 \\
MKTRETURN & 6.07 & 7.80 & 18.49 & -48.59 & 29.35 \\
LOANTA & 64.60 & 64.54 & 3.20 & 59.16 & 70.73 \\
SNONINT & 15.59 & 14.46 & 3.08 & 11.58 & 21.47 \\
TERM & 1.69 & 1.61 & 1.30 & -0.26 & 3.71 \\
\hline
\end{tabular}


Table 2 Descriptive statistics for firm-level variables during 1991-2013.

Panels A, B, and C of this table provide descriptive statistics for firm-level variables during 1991-2013 for the full sample $(\mathrm{N}=36,136)$, the large firm sample $(\mathrm{N}=18,060)$, and the small firm sample $(\mathrm{N}=18,076)$, respectively. Investment ratio (CAPEXTA) is measured as the ratio of capital expenditure to one-year lagged total assets. TA denotes total assets in USD. We deflate the value of total assets by US CPI. Leverage (LEV) is computed as the ratio of total debt to total assets. Cash/Assets (CASHTA) is the ratio of cash to total assets. Current Assets/Current Liabilities (CACL) is the ratio of current assets to current liabilities. Market-to-book ratio (MBV) is the ratio of the market value of equity to the book value of equity. Return on Assets (ROA) is measured as the ratio of EBIT to total assets. Dividend/Asset (DIVTA) is the ratio of dividend to total assets.

\begin{tabular}{|c|c|c|c|c|c|}
\hline & Mean & Median & S.D. & Min & Max \\
\hline \multicolumn{6}{|l|}{ Panel A: Full Sample } \\
\hline CAPEXTA $(\%)$ & 6.71 & 4.23 & 7.85 & 0.02 & 46.93 \\
\hline Real TA in million USD & $3,869.04$ & 651.62 & $9,264.86$ & 2.95 & $58,703.57$ \\
\hline LNTA & 6.45 & 6.48 & 2.06 & 1.08 & 10.98 \\
\hline CACL & 2.75 & 1.97 & 2.61 & 0.32 & 17.11 \\
\hline CASHTA & 0.19 & 0.09 & 0.22 & 0.00 & 0.93 \\
\hline CATA & 0.49 & 0.49 & 0.25 & 0.05 & 0.98 \\
\hline $\operatorname{LEV}(\%)$ & 22.10 & 19.07 & 20.54 & 0.00 & 96.49 \\
\hline MBV & 2.75 & 1.94 & 4.22 & -13.53 & 26.87 \\
\hline $\operatorname{ROA}(\%)$ & 2.76 & 7.93 & 24.67 & -136.77 & 39.75 \\
\hline DIVTA & 0.01 & 0.00 & 0.02 & 0.00 & 0.14 \\
\hline \multicolumn{6}{|l|}{ Panel B: Large firms } \\
\hline CAPEXTA $(\%)$ & 6.98 & 4.81 & 7.29 & 0.02 & 46.93 \\
\hline Real TA in million USD & $7,529.03$ & $2,619.97$ & $12,039.15$ & 516.34 & $58,703.57$ \\
\hline LNTA & 8.11 & 7.87 & 1.20 & 6.25 & 10.98 \\
\hline CACL & 1.99 & 1.62 & 1.53 & 0.32 & 17.11 \\
\hline CASHTA & 0.11 & 0.06 & 0.13 & 0.00 & 0.93 \\
\hline CATA & 0.39 & 0.37 & 0.22 & 0.05 & 0.98 \\
\hline $\operatorname{LEV}(\%)$ & 28.32 & 27.04 & 18.47 & 0.00 & 96.49 \\
\hline MBV & 2.70 & 2.00 & 3.68 & -13.53 & 26.87 \\
\hline ROA (\%) & 8.90 & 8.91 & 10.17 & -136.77 & 39.75 \\
\hline DIVTA & 0.01 & 0.01 & 0.02 & 0.00 & 0.14 \\
\hline \multicolumn{6}{|l|}{ Panel C: Small firms } \\
\hline CAPEXTA $(\%)$ & 6.43 & 3.59 & 8.36 & 0.02 & 46.93 \\
\hline Real TA in million USD & 212.28 & 157.11 & 185.31 & 2.95 & 821.50 \\
\hline LNTA & 4.79 & 5.06 & 1.26 & 1.08 & 6.71 \\
\hline CACL & 3.51 & 2.50 & 3.19 & 0.32 & 17.11 \\
\hline CASHTA & 0.26 & 0.18 & 0.26 & 0.00 & 0.93 \\
\hline CATA & 0.59 & 0.62 & 0.24 & 0.05 & 0.98 \\
\hline $\operatorname{LEV}(\%)$ & 15.89 & 7.56 & 20.64 & 0.00 & 96.49 \\
\hline MBV & 2.80 & 1.86 & 4.69 & -13.53 & 26.87 \\
\hline $\operatorname{ROA}(\%)$ & -3.38 & 6.07 & 32.22 & -136.77 & 39.75 \\
\hline DIVTA & 0.01 & 0.00 & 0.02 & 0.00 & 0.14 \\
\hline
\end{tabular}


Table 3 Correlation coefficient matrix of key firm-level variables.

This table presents correlation coefficients for key firm-level variables for a sample of publicly listed non-financial firms in the US, totaling 36,136 firm-year observations. LNCAPEXTA is the natural logarithm of CAPEXTA, which is measured as the ratio of capital expenditure to one-year lagged total assets. LNTA is the natural logarithm of real total assets in million USD. CACL is the ratio of current assets to current liabilities. CASHTA is the ratio of cash to total assets. CATA is the ratio of current assets to total assets. LEV is the ratio of total debt to total assets (in \%). MBV is the ratio of the market value of equity to the book value of equity. ROA is the ratio of EBIT to total assets (in \%). DIVTA is the ratio of dividend to total assets. All variables are winsorized at the 1 st and 99th percentiles. Symbols ***,**, and * denote statistical significance at the $1 \%, 5 \%$ and $10 \%$ levels, respectively.

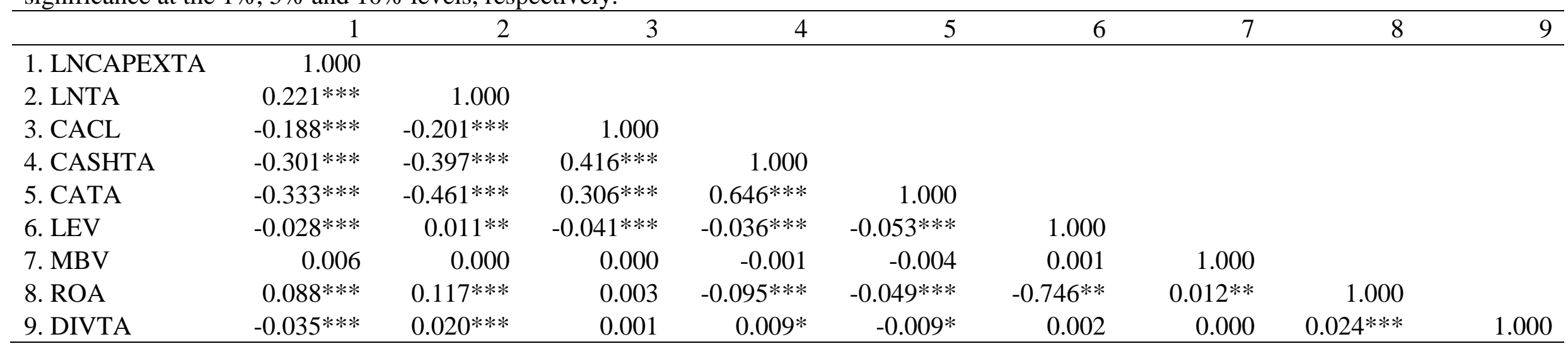


Table 4 Panel OLS regressions with the investment rate as the dependent variable.

This table presents the results of panel OLS regressions of investment rate, measured as the natural logarithm of the ratio of capital expenditure to one-period lagged total assets, on bank systemic risk for a sample of non-financial firms during 1991-2013. Columns (1) and (2) present the results of the baseline model without fixed effects and with fixed effects, respectively. The effect of bank systemic risk with respect to "bank funding maturity" is presented in column (3). The effect of bank systemic risk with respect to "bank asset commonality" is shown in columns (4) and (5). We measure a country-level bank systemic risk using three measures: SYSRISK1, SYSRISK2, and SYSRISK3. SYSRISK1, defined as the cross-sectional mean of the share of short-term debt as \% of long-term debt of publicly listed banks in a country, is a proxy for bank funding maturity. SYSRISK2 is defined as the inverse of the cross-sectional standard deviation of the ratio of loan to assets (in \%) of publicly listed banks. SYSRISK3 is defined as the inverse of the cross-sectional deviation of the share of non-interest income as \% of net revenue of publicly listed banks. SYSRISK2 and SYSRISK 3 measure bank asset commonality. All explanatory variables are one-period lagged. $\Delta$ GDP denotes the GDP growth rate (in \%); LNBSD is the natural logarithm of the percentage share of domestic credit to private sector by banks to GDP. LNEXPORT is the natural logarithm of the percentage share of export to GDP; MKTRETURN denotes stock market return (in \%), measured as the first difference in the natural logarithm of the stock market index; LOANTA is the average ratio of total loans to assets of banks in a country; SNONINT is the average share of non-interest income to net revenue of banks in a country. Other variable definitions are provided in Table 2. Standard errors are robust to heteroskedasticity and serial correlation and are clustered at the firm level. We report standard errors in parentheses. Symbols $* * *, * *$, and $*$ denote statistical significance at the $1 \%, 5 \%$ and $10 \%$ levels, respectively.

\begin{tabular}{|c|c|c|c|c|c|}
\hline & (1) & (2) & (3) & (4) & (5) \\
\hline Constant & $3.677 * * *$ & $3.971 * * *$ & $3.862 * * *$ & $4.275^{* * *}$ & $3.470 * * *$ \\
\hline $\mathrm{LNTA}_{\mathrm{t}-1}$ & $0.030 * * *$ & $-0.159 * * *$ & $-0.159 * * *$ & $-0.159 * * *$ & $-0.159 * * *$ \\
\hline \multirow{2}{*}{ CACL $_{t-1}$} & $-0.071 * * *$ & $-0.028 * * *$ & $-0.028 * * *$ & $-0.028 * * *$ & $-0.028 * * *$ \\
\hline & $(0.006)$ & (0.004) & (0.004) & (0.004) & $(0.004)$ \\
\hline CASHTA $_{\mathrm{t}-1}$ & $-0.590 * * *$ & -0.007 & -0.011 & -0.006 & -0.008 \\
\hline $\mathrm{LEV}_{\mathrm{t}-1}$ & $(0.001)$ & $(0.000)$ & $(0.000)$ & $(0.000)$ & $(0.000)$ \\
\hline \multirow[t]{2}{*}{$\mathrm{MBV}_{\mathrm{t}-1}$} & $0.010 * * *$ & $0.007 * * *$ & $0.007 * * *$ & $0.007 * * *$ & $0.007 * * *$ \\
\hline & $(0.002)$ & $(0.001)$ & $(0.001)$ & $(0.001)$ & $(0.001)$ \\
\hline \multirow[t]{2}{*}{$\mathrm{ROA}_{\mathrm{t}-1}$} & $0.009 * * *$ & $0.007 * * *$ & $0.007 * * *$ & $0.007 * * *$ & $0.007 * * *$ \\
\hline & $(0.001)$ & $(0.000)$ & $(0.000)$ & $(0.000)$ & $(0.000)$ \\
\hline
\end{tabular}




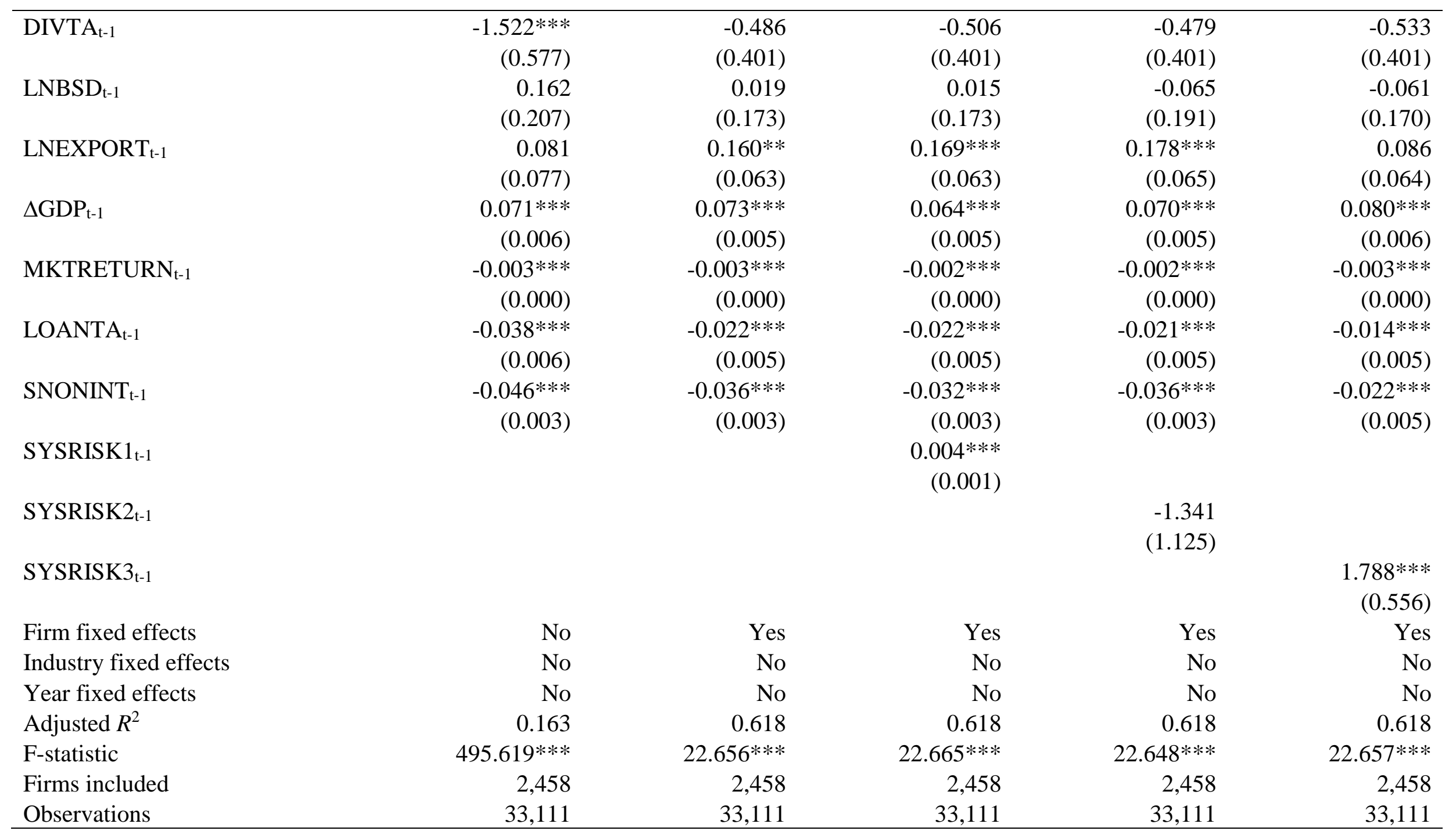


Table 5 First-stage OLS regressions of bank systemic risk.

This table reports the results of the first-stage OLS regression of bank systemic risk on macro-level factors. SYSRISK1, SYSRISK2, and SYSRISK3 are the dependent variable in columns (1), (2), and (3), respectively. $\triangle$ GDP denotes the GDP growth rate (in \%); LNEXPORT is the natural logarithm of the percentage share of export to GDP; TERM denotes term spread, which is measured as the difference in the yield on 10-year US government bond and the yield on 1-year US government bond. Newey-West standard errors, reported standard errors in parentheses, are robust to heteroskedasticity and serial correlation.

\begin{tabular}{lrrr}
\hline & $(1)$ & $(2)$ & $(3)$ \\
& SYSRISK1 & SYSRISK2 & SYSRISKC3 \\
\hline Constant & $53.555^{* *}$ & $0.045^{* *}$ & $0.302^{*}$ \\
& $(20.132)$ & $(0.019)$ & $(0.170)$ \\
GDP & $1.928^{* * *}$ & -0.001 & 0.001 \\
LNEXPORT & $(0.426)$ & $(0.001)$ & $(0.003)$ \\
& $-19.656^{* *}$ & $0.015^{*}$ & -0.073 \\
TERM & $(8.516)$ & $(0.008)$ & $(0.069)$ \\
& -1.077 & 0.001 & $-0.008^{*}$ \\
Adjusted $R^{2}$ & $(0.936)$ & $(0.001)$ & $(0.005)$ \\
F-statistic & 0.339 & 0.111 & 0.098 \\
Observations & $4.769^{* *}$ & 1.915 & 1.796 \\
\hline
\end{tabular}


Table 6 Two-stage panel OLS regressions with the investment rate as the dependent variable.

This table presents the results of the second-stage panel OLS regressions of investment rate, measured as the natural logarithm of the ratio of capital expenditure to one-period lagged total assets, on bank systemic risk for a sample of non-financial firms during 1991-2013. Columns (1), (2), and (3) present the results of the second-stage panel OLS regressions, while columns (4), (5), and (6) present the results of the second stage dynamic OLS regressions. We measure a country-level bank systemic risk using three measures. BSR1, BSR2, and BSR3 are the residuals obtained from the regression (3) where the dependent variable is SYSRISK1, SYSRISK2, and SYSRISK3, respectively. SYSRISK1 is defined as the cross-sectional mean of the share of short-term debt as \% of long-term debt of publicly listed banks in a country. SYSRISK2 is defined as the inverse of the cross-sectional standard deviation of the ratio of loan to assets (in \%) of publicly listed banks. SYSRISK3 is defined as the inverse of the cross-sectional deviation of the share of non-interest income as \% of net revenue of publicly listed banks. All explanatory variables are one-period lagged. $\triangle \mathrm{GDP}$ denotes the GDP growth rate (in \%); LNBSD is the natural logarithm of the percentage share of domestic credit to private sector by banks to GDP. LNEXPORT is the natural logarithm of the percentage share of export to GDP; MKTRETURN denotes stock market return (in \%), measured as the first difference in the natural logarithm of the stock market index; LOANTA is the average ratio of total loans to assets of banks in a country; SNONINT is the average share of non-interest income to net revenue of banks in a country. Other variable definitions are provided in Table 2. Standard errors are robust to heteroskedasticity and serial correlation and are clustered at the firm level. We report standard errors in parentheses. Symbols ***, **, and * denote statistical significance at the 1\%, 5\% and 10\% levels, respectively.

\begin{tabular}{|c|c|c|c|c|c|c|}
\hline & (1) & (2) & (3) & (4) & (5) & (6) \\
\hline Constant & $3.944 * * *$ & $4.118 * * *$ & $3.862 * * *$ & $2.377 * * *$ & $2.434 * * *$ & $1.992 * * *$ \\
\hline LNCAPEXTA $_{\mathrm{t}-1}$ & & & & $0.392 * * *$ & $0.391 * * *$ & $0.392 * * *$ \\
\hline \multirow[t]{2}{*}{ LNTA $_{t-1}$} & $-0.159 * * *$ & $-0.159 * * *$ & $-0.159 * * *$ & $-0.193 * * *$ & $-0.194 * * *$ & $-0.193 * * *$ \\
\hline & $(0.012)$ & $(0.012)$ & $(0.012)$ & $(0.008)$ & $(0.008)$ & $(0.008)$ \\
\hline $\mathrm{CACL}_{\mathrm{t}-1}$ & $-0.028 * * *$ & $-0.028 * * *$ & $-0.028 * * *$ & $-0.020 * * *$ & $-0.020 * * *$ & $-0.020 * * *$ \\
\hline CASHTA $_{t-1}$ & $(0.061)$ & $(0.061)$ & $(0.061)$ & $(0.047)$ & $(0.047)$ & $(0.047)$ \\
\hline \multirow[t]{2}{*}{$\mathrm{LEV}_{\mathrm{t}-1}$} & $-0.007 * * *$ & $-0.007 * * *$ & $-0.007 * * *$ & $-0.005 * * *$ & $-0.005 * * *$ & $-0.005 * * *$ \\
\hline & $(0.000)$ & $(0.000)$ & $(0.000)$ & $(0.000)$ & $(0.000)$ & $(0.000)$ \\
\hline \multirow[t]{2}{*}{$\mathrm{MBV}_{\mathrm{t}-1}$} & $0.007 * * *$ & $0.007 * * *$ & $0.007 * * *$ & 0.001 & 0.001 & 0.001 \\
\hline & $(0.001)$ & $(0.001)$ & $(0.001)$ & $(0.001)$ & $(0.001)$ & $(0.001)$ \\
\hline
\end{tabular}




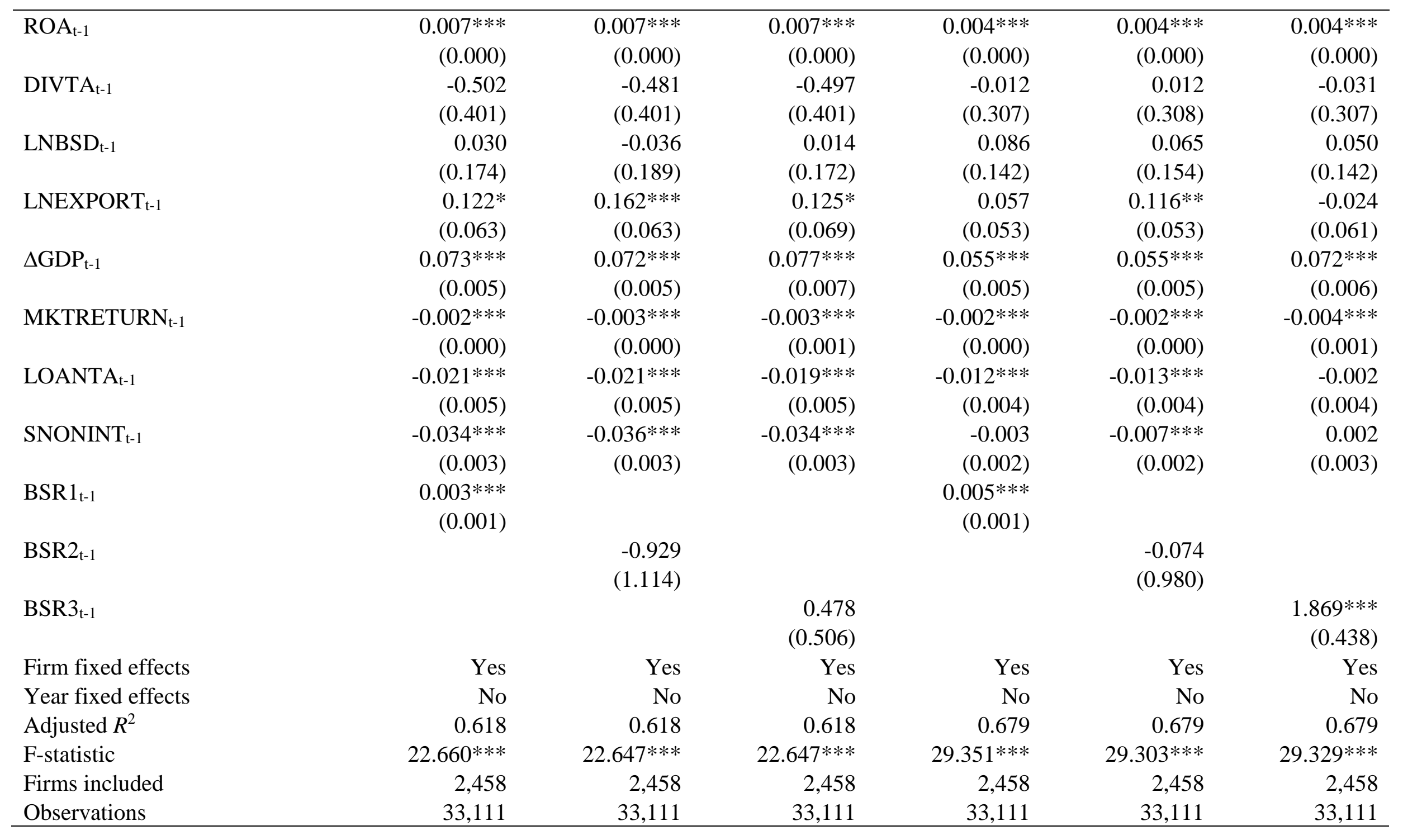


Table 7 Two-stage panel OLS regressions with the investment rate as the dependent variable.

This table presents the results of the second-stage panel OLS regressions of investment rate, measured as the natural logarithm of the ratio of capital expenditure to one-period lagged total assets, on bank systemic risk for a sample of non-financial firms during 1991-2013. We test the interaction effects of bank systemic risk and firm characteristics on investment by interacting bank systemic risk with leverage (in column (1)), growth opportunities (in column (2)), firm size (in columns (3) and (4)), and firm performance (in column (5)). We measure a country-level bank systemic risk using BSR1 which is the residuals obtained from the regression (3) where the dependent variable is SYSRISK1. SYSRISK1 is defined as the cross-sectional mean of the share of short-term debt as \% of long-term debt of publicly listed banks in a country. All explanatory variables are one-period lagged. $\triangle$ GDP denotes the GDP growth rate (in \%); LNBSD is the natural logarithm of the percentage share of domestic credit to private sector by banks to GDP. LNEXPORT is the natural logarithm of the percentage share of export to GDP; MKTRETURN denotes stock market return (in \%), measured as the first difference in the natural logarithm of the stock market index; LOANTA is the average ratio of total loans to assets of banks in a country; SNONINT is the average share of non-interest income to net revenue of banks in a country. Other variable definitions are provided in Table 2. Standard errors are robust to heteroskedasticity and serial correlation and are clustered at the firm level. We report standard errors in parentheses. Symbols ***,**, and * denote statistical significance at the $1 \%$, 5\% and $10 \%$ levels, respectively.

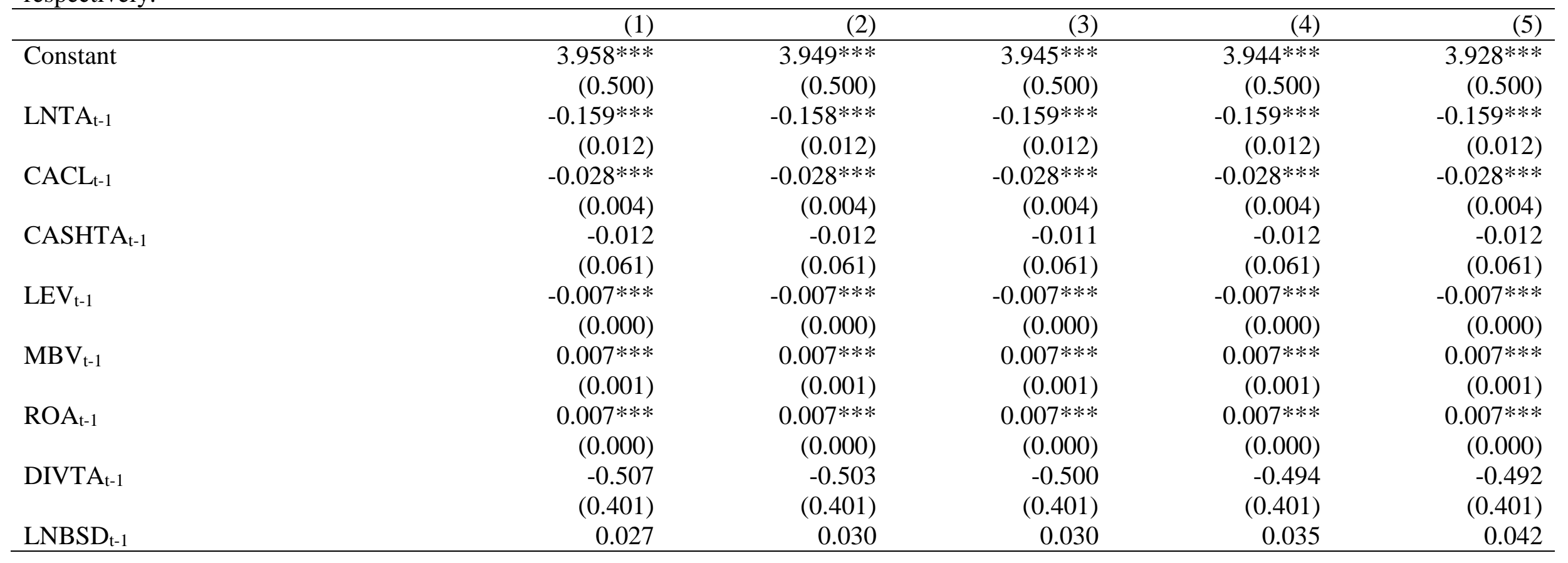




\begin{tabular}{|c|c|c|c|c|c|}
\hline LNEXPORT $_{\mathrm{t}-1}$ & $(0.174)$ & $(0.174)$ & $(0.174)$ & $(0.174)$ & $(0.174)$ \\
\hline$\Delta \mathrm{GDP}_{\mathrm{t}-1}$ & $0.073 * * *$ & $0.073 * * *$ & $0.073 * * *$ & $0.073 * * *$ & $0.073 * * *$ \\
\hline \multirow{2}{*}{ MKTRETURN $_{\mathrm{t}-1}$} & $-0.002 * * *$ & $-0.002 * * *$ & $-0.002 * * *$ & $-0.002 * * *$ & $-0.002 * * *$ \\
\hline & $(0.000)$ & $(0.000)$ & $(0.000)$ & $(0.000)$ & $(0.000)$ \\
\hline \multirow{2}{*}{ LOANTA $_{t-1}$} & $-0.021 * * *$ & $-0.022 * * *$ & $-0.021 * * *$ & $-0.022 * * *$ & $-0.022 * * *$ \\
\hline & $(0.005)$ & $(0.005)$ & $(0.005)$ & $(0.005)$ & $(0.005)$ \\
\hline SNONINT $_{\mathrm{t}-1}$ & $(0.003)$ & $(0.003)$ & $(0.003)$ & $(0.003)$ & $(0.003)$ \\
\hline \multirow[t]{2}{*}{$\operatorname{BSR} 1_{t-1}$} & $0.005 * * *$ & $0.002 * *$ & $0.004 * * *$ & $0.007 * * *$ & $0.004 * * *$ \\
\hline & $(0.001)$ & $(0.001)$ & $(0.001)$ & $(0.003)$ & $(0.001)$ \\
\hline \multirow[t]{2}{*}{$\mathrm{BSR}_{\mathrm{t}-1} \times \mathrm{LEV}_{\mathrm{t}-1}$} & $0.000 * *$ & & & & \\
\hline & $(0.000)$ & & & & \\
\hline$B S R 1_{t-1} \times M V_{t-1}$ & & $\begin{array}{r}0.000 \\
(0.000)\end{array}$ & & & \\
\hline $\mathrm{BSR}_{\mathrm{t}-1} \times \mathrm{ROA}_{\mathrm{t}-1}$ & & & & & $\begin{array}{c}0.000^{*} \\
(0.000)\end{array}$ \\
\hline Firm fixed effects & Yes & Yes & Yes & Yes & Yes \\
\hline Year fixed effects & No & No & No & No & No \\
\hline Adjusted $R^{2}$ & 0.618 & 0.618 & 0.618 & 0.618 & 0.618 \\
\hline F-statistic & $22.655^{* * *}$ & $22.652 * * *$ & $22.651 * * *$ & $22.653 * * *$ & $22.654 * * *$ \\
\hline Firms included & 2,458 & 2,458 & 2,458 & 2,458 & 2,458 \\
\hline Observations & 33,111 & 33,111 & 33,111 & 33,111 & 33,111 \\
\hline
\end{tabular}


Table 8 Robustness tests: Panel OLS regressions with the investment rate as the dependent variable.

This table presents the results of panel OLS regressions of investment rate, measured as the natural logarithm of the ratio of capital expenditure to one-period lagged total assets, on bank systemic risk for a sample of non-financial firms during 1991-2013. We measure a country-level bank systemic risk using three measures: SYSRISK1, SYSRISK2, and SYSRISK3. SYSRISK1, defined as the cross-sectional mean of the share of short-term debt as \% of long-term debt of publicly listed banks in a country, is a proxy for bank funding maturity. SYSRISK2 is defined as the inverse of the cross-sectional standard deviation of the ratio of loan to assets (in \%) of publicly listed banks. SYSRISK3 is defined as the inverse of the cross-sectional deviation of the share of non-interest income as $\%$ of net revenue of publicly listed banks. SYSRISK2 and SYSRISK 3 measure bank asset commonality. All explanatory variables are one-period lagged. $\triangle$ GDP denotes the GDP growth rate (in \%); LNBSD is the natural logarithm of the percentage share of domestic credit to private sector by banks to GDP. LNEXPORT is the natural logarithm of the percentage share of export to GDP; MKTRETURN denotes stock market return (in \%), measured as the first difference in the natural logarithm of the stock market index; LOANTA is the average ratio of total loans to assets of banks in a country; SNONINT is the average share of noninterest income to net revenue of banks in a country. Risk premium (RISKPREMIUM) is measured as prime rate minus T-bill rate. Other variable definitions are provided in Table 2. Standard errors are robust to heteroskedasticity and serial correlation and are clustered at the firm level. We report standard errors in parentheses. Symbols ***,**, and * denote statistical significance at the $1 \%, 5 \%$ and $10 \%$ levels, respectively.

\begin{tabular}{|c|c|c|c|}
\hline & (1) & (2) & (3) \\
\hline Constant & $3.893 * * *$ & $4.516^{* * *}$ & $3.730 * * *$ \\
\hline LNTA $_{\mathrm{t}-1}$ & $-0.158 * * *$ & $-0.157 * * *$ & $-0.158 * * *$ \\
\hline \multirow[t]{2}{*}{$\mathrm{CACL}_{\mathrm{t}-1}$} & $-0.028 * * *$ & $-0.028 * * *$ & $-0.028 * * *$ \\
\hline & (0.004) & $(0.004)$ & $(0.004)$ \\
\hline CASHTA $_{t-1}$ & -0.015 & -0.015 & -0.015 \\
\hline $\mathrm{LEV}_{\mathrm{t}-1}$ & $(0.000)$ & $(0.000)$ & $(0.000)$ \\
\hline \multirow[t]{2}{*}{$\mathrm{MBV}_{\mathrm{t}-1}$} & $0.007 * * *$ & $0.007 * * *$ & $0.007 * * *$ \\
\hline & $(0.001)$ & $(0.001)$ & $(0.001)$ \\
\hline \multirow[t]{2}{*}{$\mathrm{ROA}_{\mathrm{t}-1}$} & $0.007 * * *$ & $0.007 * * *$ & $0.007 * * *$ \\
\hline & $(0.000)$ & $(0.000)$ & $(0.000)$ \\
\hline
\end{tabular}




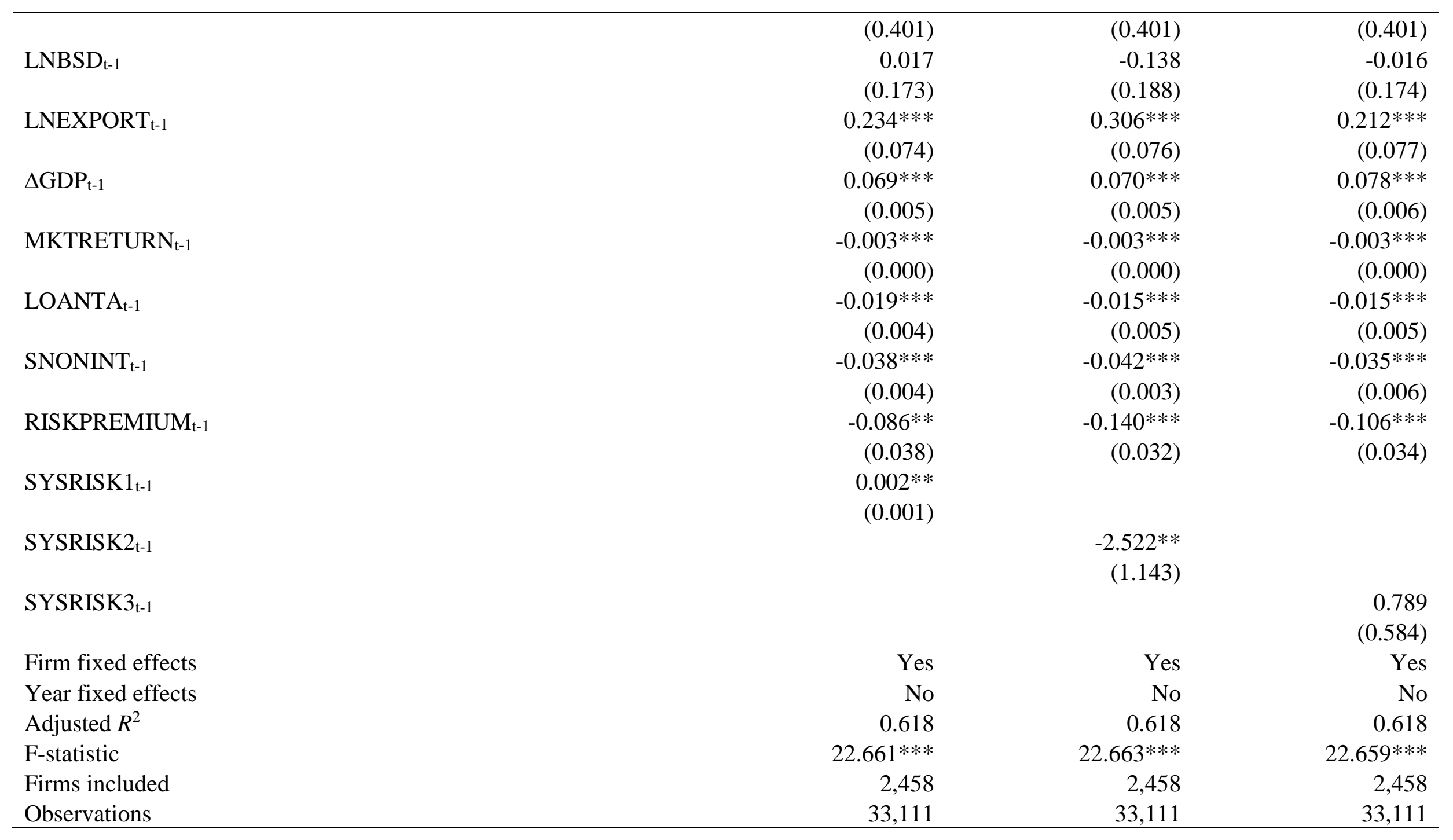


Figure 1 Bank systemic risk and corporate investment.

This figure plots a time-series pattern of the average investment rate (CAPEXTA) and three bank systemic risk measures (SYSRISK1, SYSRISK2, and SYSRISK3). SYSRISK1 is defined as the cross-sectional mean of the percentage share of short-term debt to long-term debt of publicly listed banks. SYSRISK2 is defined as the inverse of the cross-sectional standard deviation of the ratio of loan to assets (in \%) of publicly listed banks. SYSRISK3 is defined as the inverse of the cross-sectional deviation of the percentage share of non-interest income to net revenue of publicly listed banks. For ease of presentation, we multiply values for SYSRISK2 and SYSRISK3 by 100.

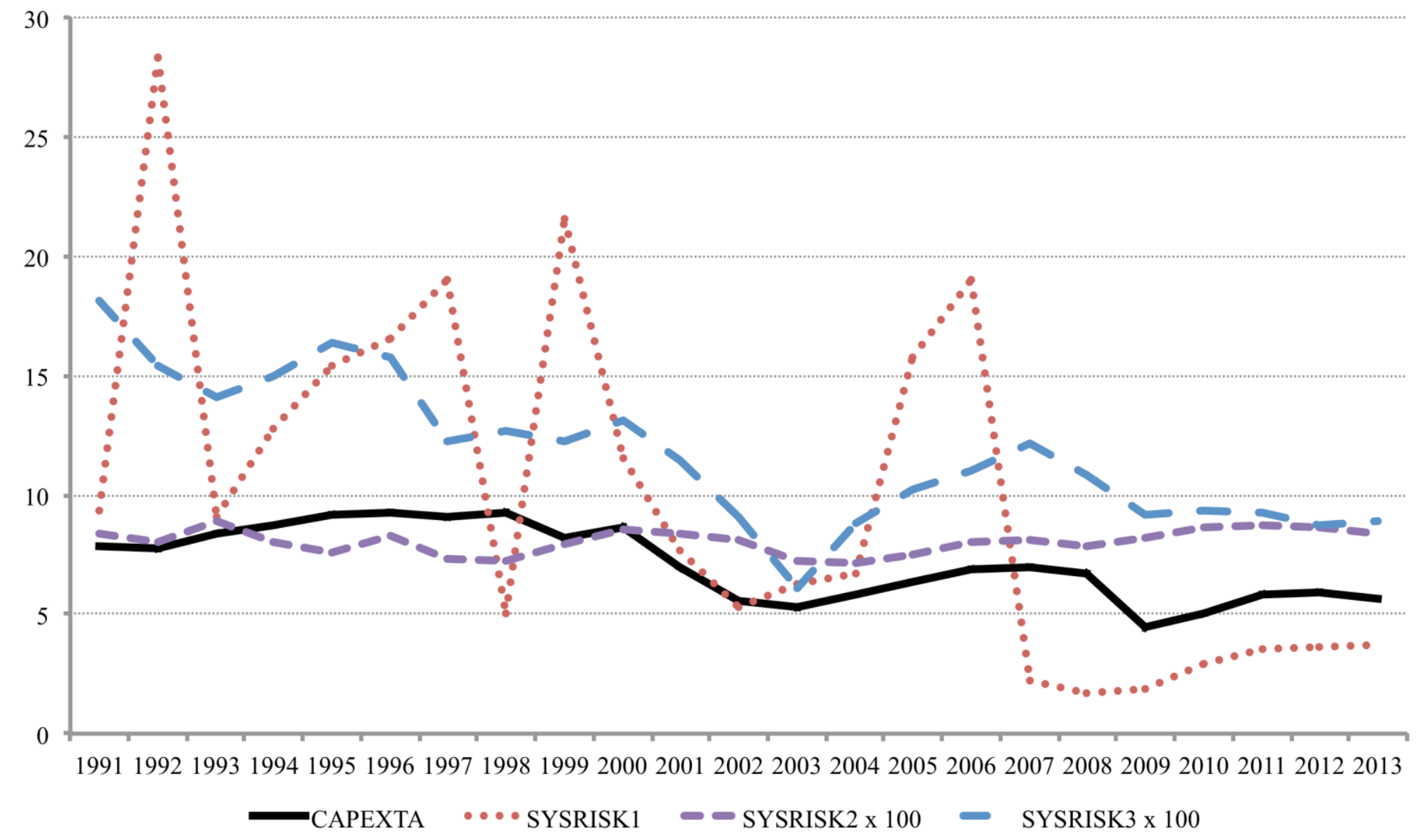

